\title{
SENTENCIA SOBRE DEBIDO PROCESO ANTE LA ADMINISTRACIÓN DEL ESTADO (CORTE INTERAMERICANA DE DERECHOS HUMANOS) CASO CLAUDE REYES Y OTROS VS. CHILE SENTENCIA DE 19 DE SEPTIEMBRE DE 2006
}

\section{Comentario de Andrés Bordali Salamanca}

En el caso Claude Reyes y otros,

la Corte Interamericana de Derechos Humanos (en adelante "la Corte Interamericana", "la Corte" o "el Tribunal"), integrada por los siguientes jueces*:

Sergio García Ramírez, Presidente;

Alirio Abreu Burelli, Vicepresidente;

Antônio A. Cançado Trindade, Juez;

Cecilia Medina Quiroga, Jueza;

Manuel E. Ventura Robles, Juez; y

Diego García-Sayán, Juez;

presentes, además,

Pablo Saavedra Alessandri, Secretario, y

Emilia Segares Rodríguez, Secretaria Adjunta;

de conformidad con los artículos 62.3 y 63.1 de la Convención Americana sobre Derechos Humanos (en adelante "la Convención" o "la Convención Americana”) y con los artículos 29, 31, 56 y 58 del Reglamento de la Corte (en adelante "el Reglamento"), dicta la presente Sentencia.

* El Juez Oliver Jackman no participó en la deliberación y firma de la presente Sentencia, ya que informó que, por motivos de fuerza mayor, no podría participar en el LXXII Período Ordinario de Sesiones del Tribunal. 


\section{INTRODUCCióN DE LA CAUSA}

1. El 8 de julio de 2005, de conformidad con lo dispuesto en los artículos 50 y 61 de la Convención Americana, la Comisión Interamericana de Derechos Humanos (en adelante "la Comisión" o "la Comisión Interamericana") sometió ante la Corte una demanda contra el Estado de Chile (en adelante "el Estado" o "Chile”). Dicha demanda se originó en la denuncia No. 12.108, recibida en la Secretaría de la Comisión el 17 de diciembre de 1998.

2. La Comisión presentó la demanda con el fin de que la Corte declare que el Estado es responsable por la violación de los derechos consagrados en los artículos 13 (Libertad de Pensamiento y de Expresión) y 25 (Derecho a la Protección Judicial) de la Convención Americana, en relación con las obligaciones establecidas en los artículos 1.1 (Obligación de Respetar los Derechos) y 2 (Deber de Adoptar Disposiciones de Derechos Interno) de la misma, en perjuicio de los señores Marcel Claude Reyes, Sebastián Cox Urrejola y Arturo Longton Guerrero.

3. Los hechos expuestos por la Comisión en la demanda habrían ocurrido entre mayo y agosto de 1998 y se refieren a la supuesta negativa del Estado de brindar a los señores Marcel Claude Reyes, Sebastián Cox Urrejola y Arturo Longton Guerrero toda la información que requerían del Comité de Inversiones Extranjeras, en relación con la empresa forestal Trillium y el Proyecto Río Cóndor, el cual era un proyecto de deforestación que se llevaría a cabo en la décimo segunda región de Chile y "p[odía] ser perjudicial para el medio ambiente e impedir el desarrollo sostenible de Chile”. La Comisión indicó que tal negativa se dio sin que el Estado "argumentar[a] una justificación válida de acuerdo con la legislación chilena", así como a que supuestamente "no [les] otorgó un recurso judicial efectivo para impugnar una violación del derecho al acceso a la información” y "no [les] aseguró los derechos al acceso a la información y a la protección judicial, ni contó con mecanismos establecidos para garantizar el derecho al acceso a la información pública".

4. Asimismo, la Comisión solicitó a la Corte que, de conformidad con el artículo 63.1 de la Convención, ordene al Estado que adopte determinadas medidas de reparación indicadas en la demanda. Por último, solicitó al Tribunal que ordene al Estado el pago de las costas y gastos generados en la tramitación del caso en la jurisdicción interna y ante los órganos del Sistema Interamericano.

\section{COMPetencia}

5. La Corte es competente para conocer el presente caso, en los términos de los artículos 62 y 63.1 de la Convención, en razón de que Chile es Estado Parte en la Convención Americana desde el 21 de agosto de 1990 y reconoció la competencia contenciosa de la Corte ese mismo día. 


\title{
$[\ldots]$ \\ III. Procedimiento Ante la Comisión
}

\section{Procedimiento ante la Corte}

$[\ldots]$

\section{Prueba}

\author{
$[\ldots]$
}

\section{Hechos Probados}

57. Con fundamento en las pruebas aportadas y considerando las manifestaciones formuladas por las partes, la Corte considera probados los siguientes hechos:

El Comité de Inversiones Extranjeras y el mecanismo de inversión extranjera regulado por el Decreto Legislativo $N^{0} 600$

57.1El Decreto Legislativo $\mathrm{N}^{\circ} 600$ de 1974, con texto refundido, coordinado y sistematizado mediante Decreto del Ministerio de Economía, Fomento y Reconstrucción No. 523 de 3 de septiembre de 1993, contiene el Estatuto de la Inversión Extranjera en Chile, el cual es uno de los mecanismos legales para materializar dicha inversión, que otorga determinados beneficios al inversor. Dicho Decreto Legislativo contempla la normativa que rige a "las personas naturales y jurídicas extranjeras, y las chilenas con residencia y domicilio en el exterior, que transfieran capitales extranjeros a Chile y que celebren un contrato de inversión extranjera"1. Dicho Decreto regula la celebración de contratos de inversión extranjera, los derechos y deberes de los inversionistas extranjeros y los regímenes aplicables a éstos, así como las funciones del Comité de Inversiones Extranjeras y de la Vicepresidencia Ejecutiva ${ }^{2}$.

57.2 El Comité de Inversiones Extranjeras "es una persona jurídica de derecho público, funcionalmente descentralizada, con patrimonio propio, [...] que se relacionará con el Presidente de la República por intermedio del Ministerio de Economía, Fomento y Reconstrucción”. El Comité se encuentra integrado por: 1) el Ministro de Economía, Fomento y Reconstrucción, quien preside; 2) el Ministro de Hacienda; 3) el Ministro de Relaciones Exteriores; 4) el Ministro del ramo res-

${ }^{1}$ Cfr. artículo 1 del Decreto Ley No 600 sobre el Estatuto de Inversiones Extranjeras publicado el 16 de diciembre de 1993 (expediente de anexos al escrito de solicitudes y argumentos, anexo 6, folios 1199 a 1212).

${ }^{2}$ Cfr. decreto Ley $\mathrm{N}^{\circ} 600$ sobre el Estatuto de Inversiones Extranjeras publicado el 16 de diciembre de 1993 (expediente de anexos al escrito de solicitudes y argumentos, anexo 6, folios 1199 a 1212). 
pectivo cuando se trate de solicitudes de inversiones vinculadas con materias que digan relación con Ministerios no representados en este Comité; 5) el Ministro de Planificación y Cooperación, y 6) el Presidente del Banco Central de Chile ${ }^{3}$.

57.3 Dicho Comité es "el único organismo autorizado, en representación del Estado de Chile, para aceptar el ingreso de capitales del exterior acogidos al [... D ]ecreto ley [N $\left.\mathrm{N}^{\circ} 600\right]$ y para establecer los términos y condiciones de los respectivos contratos" y se relacionará con el Presidente de la República por intermedio del Ministerio de Economía, Fomento y Reconstrucción. Para el cumplimiento de sus atribuciones y obligaciones "el Comité [de Inversiones Extranjeras] actuará representado por su Presidente en los casos de [...] inversiones que requieran de[l] acuerdo del Comité, según lo dispuesto en el artículo 16 [de dicho decreto], en caso contrario, actuará representado por su Vicepresidente Ejecutivo" ${ }^{4}$.

57.4La Vicepresidencia Ejecutiva del Comité de Inversiones Extranjeras, para el cumplimiento de sus atribuciones y obligaciones, tendrá las siguientes funciones: a) recibir, estudiar e informar las solicitudes de inversiones extranjeras y las demás que se presenten a la consideración del Comité; b) actuar como órgano administrativo del Comité, preparando los antecedentes y estudios que requiera; c) cumplir funciones de información, registro, estadística y coordinación respecto de las inversiones extranjeras; d) centralizar la información y el resultado del control que deban ejercer los organismos públicos respecto de las obligaciones que contraigan los titulares de inversiones extranjeras o las empresas en que éstos participen y denunciar ante los poderes y organismos públicos competentes, los delitos o infracciones de que tome conocimiento; e) realizar y agilizar los trámites ante los diferentes organismos que deban informar o dar su autorización previa para la aprobación de las diversas solicitudes que el Comité debe resolver y para la debida materialización de los contratos y resoluciones correspondientes; y f) investigar en Chile o en el extranjero sobre la idoneidad y seriedad de los peticionarios o intere$\operatorname{sados}^{5}$.

57.5El Comité de Inversiones Extranjeras recibe solicitudes de inversión extranjera en Chile a través de su Vicepresidente, a las cuales se adjuntan antecedentes de los solicitantes. Cuando los solicitantes son personas jurídicas, los antecedentes consisten, entre otros, en: nombre o razón social; tipo de sociedad; nombres de principales accionistas y otros antecedentes sociales; domicilio; actividad económi-

${ }^{3}$ Cfr. artículo 13 del Decreto Ley No. 600 sobre el Estatuto de Inversiones Extranjeras publicado el 16 de diciembre de 1993 (expediente de anexos al escrito de solicitudes y argumentos, tomo I, anexo 6, folio 1208).

${ }^{4}$ Cfr. artículo 12 del Decreto Ley No. 600 sobre el Estatuto de Inversiones Extranjeras publicado el 16 de diciembre de 1993 (expediente de anexos al escrito de solicitudes y argumentos, tomo I, anexo 6, folio 1207).

${ }^{5}$ Cfr. artículo 15 del Decreto Ley No. 600 sobre el Estatuto de Inversiones Extranjeras publicado el 16 de diciembre de 1993 (expediente de anexos al escrito de solicitudes y argumentos, tomo I, anexo 6, folio 1208); y declaración escrita rendida por el testigo Andrés Emilio Culagovski Rubio rendida el 10 de marzo de 2006 (expediente de fondo, tomo III, folio 815). 
ca; antecedentes económicos del último año; capital social; patrimonio; utilidades; países en que tienen inversiones; representante legal en Chile; descripción económica del proyecto; sector económico; región de destino de la inversión; empleos nuevos que el proyecto generará; mercado de destino; monto, objeto y composición del aporte; y datos de la sociedad receptora del aporte ${ }^{6}$.

\section{Respecto del contrato de inversión para la realización del "Proyecto Rio Cóndor" [...]}

Respecto de la solicitud de información de Marcel Claude Reyes y Arturo Longton Guerrero al Comité de Inversiones Extranjeras y la respuesta a dicha solicitud

57.12 El señor Marcel Claude Reyes es economista. En 1983 trabajó en el Banco Central como asesor del Comité de Inversiones Extranjeras y en la Unidad de Cuentas Ambientales y fue Director Ejecutivo de la Fundación Terram desde 1997 hasta 2003. Dicha organización no gubernamental tiene por finalidad, entre otras, promover la capacidad de la sociedad civil para responder a decisiones públicas sobre inversiones relacionadas con el uso de los recursos naturales, así como "participar activamente en el debate público y en la producción de información sólida científica [...] en relación al desarrollo sustentable en [Chile]"7.

57.13 El 7 de mayo de 1998 el señor Marcel Claude Reyes, en su carácter de Director Ejecutivo de la Fundación Terram, remitió una comunicación al Vicepresidente Ejecutivo del Comité de Inversiones Extranjeras, mediante la cual indicó que dicha organización se propuso "evaluar los factores comerciales, económicos y sociales del proyecto [Río Cóndor], medir el impacto sobre el medio ambiente [...] y activar el control social respecto de la gestión de los órganos del Estado que tienen o han tenido injerencia en el desarrollo del proyecto de explotación Río Cóndor"8. En la referida comunicación el Director Ejecutivo de la Fundación Terram solicitó al Comité de Inversiones que suministrara la siguiente información "de interés público"9:

${ }^{6} \mathrm{Cfr}$. formulario de solicitud de inversión extranjera (expediente de fondo, tomo III, anexo a la declaración escrita rendida por el perito Claudio Francisco Castillo Castillo el 13 de marzo de 2006, folios 897 a 901).

${ }^{7}$ Cfr. comunicación de 7 de mayo de 1998 dirigida al Vicepresidente Ejecutivo del Comité de Inversiones Extranjeras por el Director Ejecutivo de la Fundación Terram (expediente de anexos a la demanda, anexo 1.1, folios 40 y 41); declaración testimonial rendida por el señor Marcel Claude Reyes ante la Corte Interamericana durante la audiencia pública celebrada el 3 de abril de 2006; e impresión de algunos enlaces de la página web de la Fundación Terram de 9 de agosto de 2000 (expediente ante la Comisión, tomo II, folio 429).

${ }^{8}$ Cfr. comunicación de 7 de mayo de 1998 dirigida al Vicepresidente Ejecutivo del Comité de Inversiones Extranjeras por el Director Ejecutivo de la Fundación Terram (expediente de anexos a la demanda, anexo 1.1, folios 40 y 41); y declaración testimonial rendida por el señor Marcel Claude Reyes ante la Corte Interamericana durante la audiencia pública celebrada el 3 de abril de 2006.

${ }^{9}$ Cfr. comunicación de 7 de mayo de 1998 dirigida al Vicepresidente Ejecutivo del Comité de Inversiones Extranjeras por el Director Ejecutivo de la Fundación Terram (expediente de anexos a la demanda, anexo 1.1, folios 40 y 41). 
“1. Contratos celebrados entre el Estado de Chile y el Inversionista Extranjero referidos al proyecto denominado Río Cóndor, expresando fecha y Notaría en la que se suscribieron y facilitando copia de los mismos.

2. Identidad de los inversionistas de este proyecto, extranjeros y/o nacionales.

3. Antecedentes que el Comité de Inversiones Extranjeras tuvo a la vista, en Chile y en el extranjero, para asegurar la seriedad e idoneidad de (los) Inversionista(s) y los acuerdos de dicho Comité en que se tuvieron dichos antecedentes por suficientes.

4. Monto total de la inversión autorizada relacionada con el Proyecto denominado Río Cóndor, forma y plazos de ingreso del capital y existencia de créditos asociados a la misma.

5. Capital efectivamente ingresado al país a la fecha, como capitales propios, aportes de capital y créditos asociados.

6. Información que obre en poder del Comité y/o que haya demandado a otras entidades públicas o privadas referida al control respecto de las obligaciones que contraigan los titulares de inversiones extranjeras o las empresas que estos participen y si el Comité ha tomado conocimiento de alguna infracción o delito.

7. Información respecto de si el Vicepresidente Ejecutivo de[l] Comité ha ejercido la atribución que le confiere el artículo 15 bis del D[ecreto Ley $\mathrm{N}^{\circ}$ ] 600, en el sentido de solicitar de todos los servicios o empresas de los sectores público y privado, los informes y antecedentes que requiera para el cumplimiento de los fines del Comité y en el evento que así fuera, poner la misma a disposición de la Fundación" ${ }^{10}$.

57.14 El 19 de mayo de 1998 el Vicepresidente Ejecutivo del Comité de Inversiones Extranjeras se reunió con el señor Marcel Claude Reyes y con el diputado Arturo Longton Guerrero ${ }^{11}$. El referido Vicepresidente entregó "una hoja conteniendo tanto el nombre del inversionista, su razón social, como el capital que había solicitado ingresar al país"12, cuándo se había aprobado el proyecto, cuáles eran las empresas, los flujos de inversiones que se habían hecho hasta la fecha, qué tipo de proyecto era y su localización ${ }^{13}$.

${ }^{10}$ Cfr. solicitud de información de 7 de mayo de 1998 dirigida al Vicepresidente Ejecutivo del Comité de Inversión Extranjera por el Director Ejecutivo de la Fundación Terram (expediente de anexos a la demanda, anexo 1.1, folios 40 y 41).

${ }^{11}$ Cfr. declaración testimonial rendida por el señor Marcel Claude Reyes ante la Corte Interamericana durante la audiencia pública celebrada el 3 de abril de 2006; declaración testimonial rendida por el señor Eduardo Moyano Berríos ante la Corte Interamericana durante la audiencia pública celebrada el 3 de abril de 2006; y declaración escrita rendida por el testigo Arturo Longton Guerrero de marzo de 2006 (expediente sobre el fondo y eventuales reparaciones y costas, tomo III, folio 915).

${ }^{12} C f$ r. declaración testimonial rendida por el señor Marcel Claude Reyes ante la Corte Interamericana durante la audiencia pública celebrada el 3 de abril de 2006.

${ }^{13} C f r$. declaración escrita rendida por la testigo Liliana Guiditta Macchiavello Martini el 10 de marzo de 2006 (expediente de fondo, tomo III, folio 828); y declaración testimonial rendida por el señor 
57.15 El 19 de mayo de 1998 el Vicepresidente Ejecutivo del Comité de Inversiones Extranjeras remitió al señor Marcel Claude Reyes una comunicación de una página, vía facsimilar, mediante la cual manifestó que "[d]e acuerdo a lo conversado, efectivamente las cifras entregadas sólo corresponden a capital, que e[ra] lo único que se ha[bía] materializado[, que e]l Proyecto t[enía] autorización para ingresar 'créditos asociados' por US\$102.000.000 pero no ha[bía] hecho uso de tal autorización[, y que el capital] autorizado correspond[ía] a un total de US $\$ 78.500 .000 " 14$.

57.16 Los días 3 de junio y 2 de julio de 1998 el señor Marcel Claude Reyes remitió dos comunicaciones al Vicepresidente Ejecutivo del Comité de Inversiones Extranjeras, mediante las cuales reiteró su pedido de información, con base en "la obligación de transparencia a que se encuentra[n] sujet[os] los agentes del Estado y el derecho de acceso a [la] información pública tal cual se encuentra contemplado en [la] Constitución Política del Estado y en los tratados internacionales suscritos y ratificados por Chile”. Además, en dichas comunicaciones el señor Claude Reyes indicó que "no se ha[bía] recibido respuesta por parte de[l] Comité de Inversiones Extranjeras frente a la solicitud planteada" y no realizó indicación alguna sobre la información que ya había sido entregada (supra párr. 57.14 y $57.15)^{15}$.

57.17 El Vicepresidente del Comité de Inversiones Extranjeras no adoptó una decisión escrita en la cual fundamentara la denegatoria de entregar la información solicitada en los puntos 3, 6 y 7 del pedido de información original (supra párr. 57.13$)^{16}$.

57.18 En el procedimiento ante la Comisión Interamericana de Derechos Humanos (supra párr. 13), el 30 de junio de 2005 el Estado remitió a la Comisión

Eduardo Moyano Berríos ante la Corte Interamericana durante la audiencia pública celebrada el 3 de abril de 2006.

${ }^{14}$ Cfr. copia de la comunicación facsimilar de 19 de mayo de 1998 dirigida por el Vicepresidente Ejecutivo del Comité de Inversiones Extranjeras al señor Marcel Claude Reyes (expediente de anexos a la demanda, anexo 2, folio 48); y declaración testimonial rendida por el señor Marcel Claude Reyes ante la Corte Interamericana durante la audiencia pública celebrada el 3 de abril de 2006.

${ }^{15}$ Cfr. comunicaciones de 3 de junio y 2 de julio de 1998 dirigidas por el señor Marcel Claude Reyes al Vicepresidente Ejecutivo del Comité de Inversiones Extranjeras (anexos a la demanda, anexos 1.2 y 1.3, folios 43 y 46); declaración testimonial rendida por el señor Marcel Claude Reyes ante la Corte Interamericana durante la audiencia pública celebrada el 3 de abril de 2006; y declaración testimonial rendida por el señor Eduardo Moyano Berríos ante la Corte Interamericana durante la audiencia pública celebrada el 3 de abril de 2006.

${ }^{16}$ Cfr. declaración testimonial rendida por el señor Marcel Claude Reyes ante la Corte Interamericana durante la audiencia pública celebrada el 3 de abril de 2006; declaración testimonial rendida por el señor Eduardo Moyano Berríos ante la Corte Interamericana durante la audiencia pública celebrada el 3 de abril de 2006; y escrito de 13 de agosto de 1999 presentado por el Estado de Chile durante el procedimiento ante la Comisión Interamericana de Derechos Humanos (expediente ante la Comisión Interamericana de Derechos Humanos, tomo II, folios 908 a 910). 
Interamericana copia de los contratos de inversión extranjera y de cesión relativos al proyecto "Río Cóndor"17.

57.19 El Estado entregó a los señores Claude Reyes y Longton Guerrero, de forma oral o escrita, la información correspondiente a la solicitada en los puntos 1, 2, 4 y 5 del pedido de información original (supra párr. 57.13) ${ }^{18}$.

57.20 El 3 de abril de 2006 el Vicepresidente Ejecutivo del Comité de Inversiones Extranjeras en la época en que el señor Claude Reyes presentó su solicitud de información, manifestó durante la audiencia pública celebrada ante la Corte Interamericana, inter alia, que no suministró la información solicitada:

a) en el punto 3 (supra párr. 57.13), ya que "el Comité de Inversiones Extranjeras [...] no entregó antecedentes financieros propios de la empresa teniendo presente que la entrega de aquellos antecedentes iba contra el interés colectivo", el cual era "el desarrollo del país". "[N]o podía darse el caso de que las empresas extranjeras que acudían al Comité de Inversiones Extranjeras tuvieran que hacer pública esa forma información financiera, que podía ser muy relevante para ellos en relación a su competencia y, por lo tanto, ello podría inhibir el proceso de inversión extranjera”. Era una práctica del Comité de Inversiones no entregar a terceros la información financiera de la empresa que pudiera afectarla en su competencia. El Comité y el Vicepresidente definían qué era de interés colectivo;

b) en el punto 6 (supra párr. 57.13), dado que "no existía" la información de los antecedentes que podría solicitar el Comité a otras instituciones, y el Comité "no es un organismo de carácter policial"; y

c) en el punto 7 (supra párr. 57.13), dado que "[e]l Comité de Inversiones Extranjeras no tenía la función ni la capacidad propia para evaluar cada proyecto en sus méritos, contaba con algo más de 20 funcionarios, y no era tampoco necesario dado que lo que hace el Comité de Inversiones Extranjeras es que autoriza el ingreso de los capitales y el tratamiento de los capitales y hay una institucionalidad propia del país en cada uno de los campos sectoriales" 19 .

${ }^{17}$ Cfr. informe presentado por el Estado ante la Comisión Interamericana el 30 de junio de 2005 (expediente ante la Comisión, tomo I, folio 221); y escrito de alegatos finales presentado por el Estado ante la Corte el 18 de mayo de 2006 (expediente sobre el fondo y eventuales reparaciones y costas, tomo IV, folio 1264).

${ }^{18}$ Cfr. comunicación facsimilar de 19 de mayo de 1998 dirigida por el Vicepresidente Ejecutivo del Comité de Inversiones Extranjeras al señor Marcel Claude Reyes (expediente de anexos a la demanda, anexo 2, folio 48); declaración testimonial rendida por el señor Marcel Claude Reyes ante la Corte Interamericana durante la audiencia pública celebrada el 3 de abril de 2006; declaración testimonial rendida por el señor Eduardo Moyano Berríos ante la Corte Interamericana durante la audiencia pública celebrada el 3 de abril de 2006; y escrito de demanda presentado por la Comisión Interamericana (expediente sobre fondo y eventuales reparaciones y costas, tomo I, folio 54).

${ }^{19}$ Cfr. declaración testimonial rendida por el señor Eduardo Moyano Berríos ante la Corte Interamericana durante la audiencia pública celebrada el 3 de abril de 2006. 
Respecto de la práctica de la Vicepresidencia del Comité de Inversiones Extranjeras sobre entrega de información

57.21 La Vicepresidencia Ejecutiva del Comité de Inversiones Extranjeras hasta el 2002 "mantuvo el criterio de entregar sólo información de la cual era titular", tenía la práctica de no entregar información relativa a los estados financieros y a los nombres de los socios de una compañía inversora ${ }^{20}$, y consideraba que era de "carácter reservado la información referida a terceros, tales como antecedentes comerciales, propiedad intelectual o industrial, tecnología y en general los aspectos particulares del proyecto de inversión que los inversionistas extranjeros pretendían desarrollar, [...] por tratarse de antecedentes de carácter privado, propios del inversionista, que de hacerse públicos podían lesionar sus legítimas expectativas comerciales, sin que existiera fuente legal que permitiera su publicidad" 21 .

57.22 El 13 de noviembre de 2002 el Ministerio de Economía, Fomento y Reconstrucción dictó la Resolución Exenta $\mathrm{N}^{\mathrm{0}} 113$, publicada en el Diario Oficial el 24 de marzo de 2003. Dicha Resolución establece en su artículo 1 que "tendrán el carácter secretos o reservados los actos, documentos y antecedentes en atención a que su conocimiento o difusión podría afectar el interés público”, enumerando en 5 incisos los supuestos comprendidos por dicha Resolución. Además, en su artículo 2 establece en qué supuestos los actos, documentos y antecedentes tendrán el carácter de secretos o reservados en atención a que su conocimiento o difusión podría afectar el interés privado de los administrados ${ }^{22}$.

\section{Respecto de las actuaciones judiciales}

57.23 El 27 de julio de 1998 los señores "Marcel Claude Reyes, por sí y en representación de Fundación Terram, Sebastián Cox Urrejola, por sí y en representación de la ONG FORJA y Arturo Longton Guerrero, por sí, y en su calidad de [d]iputado de la República", presentaron un recurso de protección ante la Corte de Apelaciones de Santiago ${ }^{23}$. Dicho recurso se fundamentó en la supuesta violación por parte de Chile al derecho de los recurrentes a la libertad de expresión

${ }^{20}$ Cfr. declaración testimonial rendida por el señor Eduardo Moyano Berríos ante la Corte Interamericana durante la audiencia pública celebrada el 3 de abril de 2006; e informe de la señora Karen Poniachik, Vicepresidenta Ejecutiva del Comité de Inversiones Extranjeras de 20 de junio de 2005 (expediente de anexos al escrito de contestación a la demanda y de observaciones al escrito de solicitudes y argumentos, anexo 1, folio 2041).

${ }^{21} C f r$. informe de la señora Karen Poniachik, Vicepresidenta Ejecutiva del Comité de Inversiones Extranjeras, de 20 de junio de 2005 (expediente de anexos al escrito de contestación a la demanda y de observaciones al escrito de solicitudes y argumentos, anexo 1, folio 2042).

${ }^{22}$ Cfr. resolución exenta $\mathrm{N}^{\circ} 113$ del Ministerio de Economía, Fomento y Reconstrucción, publicada el 24 de marzo de 2003 en el Diario Oficial (expediente de anexos al escrito de solicitudes y argumentos, anexo 6 , folio 1270 ).

${ }^{23}$ Cfr. recurso de protección presentado por Marcel Claude Reyes, Sebastián Cox Urrejola y Arturo Longton Guerrero ante la Corte de Apelaciones de Santiago el 27 de julio de 1998 (expediente de anexos a la demanda, anexo 3, folios 51 y 52). 
y de acceso a información en poder del Estado, garantizado por el artículo 19.12 de la Constitución chilena, en relación con el artículo 5.2 de la misma; el artículo 13.1 de la Convención Americana y el artículo 19.2 del Pacto Internacional de Derechos Civiles y Políticos. Solicitaron a la referida Corte de Apelaciones que ordenara al Comité de Inversiones Extranjeras que respondiera al pedido de información y pusiera a disposición de las presuntas víctimas la información, en un plazo razonable. En el texto del referido recurso de protección los recurrentes no hicieron referencia a la reunión sostenida con el Vicepresidente Ejecutivo del Comité de Inversiones Extranjeras, ni a la información que éste les habría proporcionado (supra párr. 57.14 y 57.15).

57.24 El artículo 20 de la Constitución Política de la República de Chile regula el recurso de protección, el cual puede ser interpuesto por una persona "por sí o por cualquiera a su nombre" ante la Corte de Apelaciones respectiva, cuando por "causa de actos u omisiones arbitrarios o ilegales, sufra privación, perturbación o amenaza en el legítimo ejercicio de los derechos y garantías establecidos en determinados numerales del artículo 19 específicamente descritos en el artículo 20. Procederá también el recurso de protección en el caso del número 8 del artículo 19, cuando el derecho a vivir en un medio ambiente libre de contaminación sea afectado por un acto arbitrario e ilegal imputable a una autoridad o persona determinada. Además, dicho artículo 20 también establece que la referida Corte “adoptará de inmediato las providencias que juzgue necesarias para restablecer el imperio del derecho y asegurar la debida protección del afectado, sin perjuicio de los demás derechos que pueda hacer valer ante la autoridad o los tribunales correspondientes" 24.

57.25 El 29 de julio de 1998 la Corte de Apelaciones de Santiago emitió una resolución, mediante la cual declaró inadmisible el recurso de protección interpuesto, con base en que de "los hechos descritos [...] y de los antecedentes aparejados al recurso, se desprende que éste adolece de manifiesta falta de fundamento". Además, la Corte de Apelaciones señaló que tenía presente que "el recurso de protección tiene por objeto restablecer el imperio del derecho cuando éste ha sido quebrantado por actos u omisiones arbitrarias o ilegales que amenazan, perturban o privan del ejercicio legítimo de alguna de las garantías taxativamente numeradas en el artículo 20 de la Constitución Política de la República, dejando a salvo las demás acciones legales". La referida resolución no contiene otra fundamentación que la señalada anteriormente, y se indica que se adopta dicha decisión de "conformidad con lo dispuesto en el No. 2 del Auto Acordado de [la] Excma. Corte Suprema [publicado el] 9 de junio de [1998]"25.

${ }^{24}$ Cfr. Constitución Política de la República de Chile de 8 de agosto de 1980 (prueba para mejor resolver incorporada por la Corte Interamericana, disponible en http:/www.bcn.cl/pags/legislación/leyes/ constitución_politica.htm).

${ }^{25}$ Cfr. resolución emitida por la Corte de Apelaciones de Santiago el 29 de julio de 1998 (expediente de anexos a la demanda, anexo 4, folio 73). 
57.26 El Auto Acordado de la Corte Suprema de Chile "sobre Tramitación del Recurso de Protección de Garantías Constitucionales” emitido el 24 de junio de 1992, fue modificado por "Auto Acordado sobre Tramitación y Fallo del Recurso de Protección el 4 de mayo de 1998, publicado el 9 de junio de 1998. En el No. 2 de este último, la Corte Suprema acordó que: “el Tribunal examinará si ha sido interpuesto en tiempo y si tiene fundamentos suficientes para acogerlo a tramitación. Si en opinión unánime de sus integrantes su presentación ha sido extemporánea o adolece de manifiesta falta de fundamento lo declarará inadmisible desde luego por resolución someramente fundada, la que no será susceptible de recurso alguno, salvo el de reposición ante el mismo tribunal" 26.

57.27 El 31 de julio de 1998 el abogado de las presuntas víctimas interpuso un recurso de reposición ante la Corte de Apelaciones de Santiago, mediante el cual solicitó a dicha Corte "se sirva reponer la resolución de [...] 29 de julio [de 1998 ...] dejándola sin efecto, declarando admisible el [recurso de protección]”27. En dicho recurso, además de exponer los alegatos de derecho sobre la supuesta violación del derecho a acceder a la información solicitada, indicó que dicha resolución no contiene justificación de fondo relacionada con la declaración de inadmisibilidad y "no se condice con lo dispuesto en el No. 2 del Autoacordado sobre Tramitación y Fallo del Recurso de Protección”, el cual dispone que "la declaración de inadmisibilidad deberá ser 'someramente fundada". En dicho recurso el referido abogado señaló que la declaración de inadmisibilidad "importa una violación a lo dispuesto en el artículo 5 inciso 2 de la C[onstitución ..., en relación con el artículo 25 de la Convención Americana”.

57.28 El 31 de julio de 1998 el abogado de las presuntas víctimas presentó un recurso de queja ante la Corte Suprema de Chile en contra de los Ministros de la Corte de Apelaciones de Santiago que firmaron la resolución de 29 de julio de 1998 (supra párr. 57.25) y requirió que se dispusiera que "los recurridos informen en el menor tiempo posible, y en definitiva, hacer lugar al mismo, poniendo inmediato remedio al mal que lo motiva, enmendando conforme a derecho la resolución adoptada con falta grave o abuso y adoptando las demás medidas que correspondan de acuerdo a la ley"28.

57.29 El artículo 545 del Código Orgánico de Tribunales establece que el recurso de queja tiene por finalidad "corregir las faltas o abusos graves cometidos en la dictación de resoluciones de carácter jurisdiccional”. Sólo procederá cuando la falta

${ }^{26}$ Cfr. auto acordado de la Corte Suprema de Chile "sobre Tramitación del Recurso de Protección de Garantías Constitucionales” emitido el 24 de junio de 1992; y auto acordado de la Corte Suprema de Chile "sobre Tramitación y Fallo del Recurso de Protección" emitido el 4 de mayo de 1998 (expediente ante la Comisión, Tomo II, folios 1039 a 1050).

${ }^{27}$ Cfr. recurso de reposición interpuesto el 31 de julio de 1998 por el abogado de las presuntas víctimas ante la Corte de Apelaciones de Santiago (expediente de anexos a la demanda, anexo 5, folio 76).

${ }^{28}$ Cfr. recurso de queja interpuesto por el abogado de las presuntas víctimas ante la Corte Suprema de Chile el 31 de julio de 1998 (expediente de anexos a la demanda, anexo 7, folio 94). 
o abuso se cometa en sentencia interlocutoria que ponga fin al juicio o haga imposible su continuación o definitiva, y que no sean susceptibles de recurso alguno, ordinario o extraordinario" 29 .

57.30 El 6 de agosto de 1998 la Corte de Apelaciones de Santiago declaró "no ha lugar a la reposición solicitada"30 (supra párr. 57.27).

57.31 El 18 de agosto de 1998 la Corte Suprema declaró inadmisible el recurso de queja interpuesto por el abogado de las presuntas víctimas (supra párr. 57.28), con base en que "no se da en la especie el presupuesto de admisibilidad", dado que la resolución que declaró inadmisible el recurso de protección (supra párr. 57.25), de conformidad con el auto acordado sobre tramitación y fallo de dicho recurso, era recurrible a través del recurso de reposición ${ }^{31}$.

\section{Respecto del marco jurídico del derecho de acceso a la información bajo el control del Estado y la reserva o secreto de actos y documentos en Chile}

57.32 La Constitución Política de Chile en su artículo 19 número 12 asegura a todas las personas "[l]a libertad de emitir opinión y la de informar, sin censura previa, en cualquier forma y por cualquier medio, sin perjuicio de responder de los delitos y abusos que se cometan en el ejercicio de estas libertades, en conformidad a la ley, la que deberá ser de quórum calificado"32. Dicho artículo también contempla "[e]l derecho de presentar peticiones a la autoridad, sobre cualquier asunto de interés público o privado, sin otra limitación que la de proceder en términos respetuosos y convenientes" 33 .

57.33 La Ley Orgánica Constitucional de Bases Generales de la Administración del Estado $\mathrm{N}^{\circ} 18.575$ de 1986, vigente en la época de los hechos, no contenía disposiciones que hicieran referencia al derecho de acceso a la información bajo el control del Estado y a los principios de transparencia y publicidad de la Administración. Dicha ley tampoco consagraba un procedimiento para poder acceder a la información que tuvieran los órganos administrativos ${ }^{34}$.

57.34 El 18 de abril de 1994 se publicó en el Diario Oficial el Decreto Supremo No 423, mediante el cual se creó la Comisión Nacional de Ética Pública, inter alia, con el propósito de promover una reflexión informada sobre el tema de la ética pública, involucrando de manera activa a los distintos poderes del Estado y secto-

\footnotetext{
${ }^{29}$ Cfr. artículo 545 del Código Orgánico de Tribunales (expediente ante la Comisión, tomo II, folio 1054).

${ }^{30}$ Cfr. resolución de la Corte de Apelaciones de Santiago de 6 de agosto de 1998 (expediente de anexos a la demanda, anexo 6 , folio 89).

${ }^{31} \mathrm{Cfr}$. sentencia emitida por la Corte Suprema de Chile el 18 de agosto de 1998 (expediente de anexos a la demanda, anexo 8, folio 109).

${ }^{32}$ Cfr. artículo 19 número 12 de la Constitución Política de Chile, supra nota 36.

${ }^{3}$ Cfr. artículo 19 número 14 de la Constitución Política de Chile, supra nota 36.

${ }^{34}$ Cfr. ley Orgánica Constitucional de Bases Generales de la Administración del Estado N ${ }^{\circ} 18.575$ publicada en el Diario Oficial el 5 de diciembre de 1986 (expediente de anexos al escrito de contestación a la demanda y de observaciones al escrito de solicitudes y argumentos, anexo 3, folio 2025 a 2134).
} 
res de la ciudadanía. En dicho decreto se enfatizó la necesidad de "modernizar la gestión pública, orientar el desarrollo de sus funciones para el cumplimiento de sus objetivos, mejorando la eficiencia, la productividad y la calidad de las prestaciones que otorgan los servicios públicos" 35 .

57.35 El 14 de diciembre de 1999 se publicó en el Diario Oficial de la República de Chile la Ley $N^{\circ} 19.653$ sobre "Probidad administrativa aplicable a los órganos de la administración del Estado”. La Ley N 19.653 incorporó los principios de probidad, transparencia y publicidad y fijó el "derecho a recurrir al juez de letras en lo civil", solicitando amparo al derecho a requerir por escrito cierta información ${ }^{36}$. El 17 de noviembre de 2001 se publicó el Decreto con fuerza de ley (DFL) 1/19.653 que fijó el "texto refundido, coordinado y sistematizado de la Ley No. 18.575" (supra párr. 57.33). Dicha ley dispuso, inter alia, que ${ }^{37}$ :

a) "son públicos los actos administrativos de los órganos de la administración del Estado y los documentos que les sirvan de sustento o complemento directo y esencial". La publicidad se "extiende a los informes y antecedentes que las empresas privadas que presten servicios de utilidad pública y las empresas a que se refieren los incisos tercero y quinto [...] de la Ley [...] sobre Sociedades Anónimas, proporcionen a las entidades estatales encargadas de su fiscalización, en la medida que sean de interés público, que su difusión no afecte el debido funcionamiento de la empresa y que el titular de dicha información no haga uso de su derecho a denegar el acceso a la misma";

b) en caso que la información "no se encuentre a disposición del público de modo permanente, el interesado tendrá derecho a requerirla por escrito al jefe del servicio respectivo";

c) el jefe del servicio podrá denegar el acceso a la información por las causales estipuladas en la ley, pero denegada la petición por causal distinta de la de seguridad de la Nación o el interés nacional, el interesado tiene derecho a recurrir al Juez de Letras en lo Civil, y contra la sentencia que dicte ese juez se puede interponer el recurso de apelación ante la Corte de Apelaciones respectiva. En caso de que la causal invocada fuere la seguridad de la Nación o el interés nacional, la reclamación del requirente deberá deducirse ante la Corte Suprema;

d) si la información requerida puede afectar los derechos o intereses de terceros, éstos tienen la facultad de oponerse a la entrega de los documentos solicitados

${ }^{35}$ Cfr. decreto $\mathrm{N}^{\circ} 423$ emitido el 5 de abril de 1994 por el Ministerio del Interior (prueba para mejor resolver incorporada por la Corte Interamericana, disponible en http://www.chiletransparente.cl/home/doc/ DS423_1994.pdf).

${ }^{36}$ Cfr. ley $\mathrm{N}^{\mathrm{o}} 19.653$ "Probidad administrativa aplicable a los órganos de la administración del Estado" (expediente de anexos a la demanda, anexo 9, folio 113).

${ }^{37}$ Cfr. decreto con fuerza de Ley No. 1/19.653 que fija el texto refundido y sistematizado de la Ley No. 18.575, Ley Orgánica Constitucional de Bases Generales de la Administración del Estado (expediente de anexos al escrito de solicitudes y argumentos, anexo 2, folios 1128 a 1157). 
mediante la presentación de un escrito que no requiere expresión de causa, luego de que se le otorga oportunidad para ello. Aún sin oposición de los terceros, el jefe superior del órgano requerido puede estimar que "la divulgación de la información involucrada afecta sensiblemente los derechos o intereses de los terceros titulares de la misma";

e) el jefe superior del órgano requerido debe proporcionar la documentación que se le solicite, salvo que concurra alguna de las causales que lo autorizan a negarse. La negativa debe formularse por escrito y contener las razones que motivan tal decisión. Las únicas causales por las cuales el Estado puede denegar la entrega de los documentos o antecedentes requeridos a la Administración son:

1) la reserva o secreto establecidos en disposiciones legales o reglamentarias;

2) que la publicidad impida o entorpezca el debido cumplimiento de las funciones del órgano requerido;

3) la oposición deducida en tiempo y forma por los terceros a quienes se refiere o afecta la información contenida en los documentos requeridos;

4) que la divulgación o entrega de los documentos o antecedentes requeridos afecte sensiblemente los derechos o intereses de terceras personas, según calificación fundada efectuada por el jefe superior del órgano requerido; $y$

5) que la publicidad afecte la seguridad de la Nación o el interés nacional.

f) uno o más reglamentos establecerán los casos de secreto o reserva de la documentación y antecedentes que obren en poder de los órganos de la Administración del Estado.

57.36 El 28 de enero de 2001 el Ministro Secretario General de la Presidencia promulgó el Decreto Supremo No 26, que establece el Reglamento sobre el Secreto o Reserva de los Actos y Documentos de la Administración del Estado, el cual fue publicado el 7 de mayo de 2001. Dicho reglamento establece que para que el órgano administrativo esté en condiciones de entregar la información requerida, ésta debe referirse a actos administrativos o a documentos que le sirvan de sustento o complemento directo o esencial ${ }^{38}$ y define lo que debe entenderse por acto administrativo, documento, documento de respaldo, sustento o complemento directo, sustento o complemento esencial y actos o documentos que se encuentran a disposición permanente del público ${ }^{39}$. Además, el mencionado Reglamento establece que:

${ }^{38}$ Cfr. artículo 2 del Reglamento sobre el Secreto o Reserva de los Actos y Documentos de la Administración del Estado (expediente de anexos al escrito de solicitudes y argumentos, tomo I, anexo 3, folio 1159).

${ }^{39}$ Cfr. artículo 3 letras d) y e) del Reglamento sobre el Secreto o Reserva de los Actos y Documentos de la Administración del Estado (expediente de anexos al escrito de solicitudes y argumentos, tomo I, anexo 3 , folios 1159 a 1163). 
a) son públicos los informes de las empresas privadas que presten servicios de utilidad pública o empresas cuyo dueño sea el Estado o en que designe dos o más directores de Sociedades Anónimas, en tanto que la documentación requerida corresponda a los informes y antecedentes que dichas empresas proporcionen a las entidades estatales encargadas de su fiscalización; que tales antecedentes e informes sean de interés público; que su difusión no afecte el debido funcionamiento de la empresa; y que el titular de dicha información no haga uso de su derecho a denegar el acceso a la misma ${ }^{40}$;

b) se encuentran a disposición permanente del público, aquellos actos y documentos que han sido objeto de publicación íntegra en el Diario Oficial y que están consignados en el índice que deberá llevar cada servicio ${ }^{41}$;

c) la declaración de reserva o de secreto la realiza el Jefe Superior de Servicio, mediante resolución fundada ${ }^{42}$;

d) los actos y documentos de carácter "secreto" serán conocidos sólo por las autoridades o personas a las que vayan dirigidos y por quienes deban intervenir en su estudio o resolución. Los actos y documentos de carácter "reservado" serán conocidos únicamente en el ámbito de la unidad del órgano a que sean remitidos ${ }^{43}$;

e) "[s]ólo podrán ser declarados como secretos o reservados los actos y documentos cuyo conocimiento o difusión pueda afectar el interés público o privado de los administrados", de conformidad con los criterios señalados en el artículo 8 del Reglamento, el cual incorpora dentro del interés público causales de reserva como la defensa, seguridad nacional, política exterior, relaciones internacionales, política monetaria, entre otros, y dentro del interés privado causales de reserva como expedientes relativos a procedimientos sancionatorios o disciplinarios de cualquier naturaleza, y expedientes médicos o sanitarios, entre otros ${ }^{44}$

f) los órganos de la Administración del Estado deberán clasificar los actos o documentos conforme a los criterios explicitados, en atención al grado de protección que requieren ${ }^{45}$; y

${ }^{40}$ Cfr. artículo 2 del Reglamento sobre el Secreto o Reserva de los Actos y Documentos de la Administración del Estado (expediente de anexos al escrito de solicitudes y argumentos, tomo I, anexo 3 , folios 1159 a 1163).

${ }^{41}$ Cfr. artículo 3 letra f) del Reglamento sobre el Secreto o Reserva de los Actos y Documentos de la Administración del Estado (expediente de anexos al escrito de solicitudes y argumentos, tomo I, anexo 3 , folios 1159 a 1163).

${ }^{42}$ Cfr. artículo 9 del Reglamento sobre el Secreto o Reserva de los Actos y Documentos de la Administración del Estado (expediente de anexos al escrito de solicitudes y argumentos, tomo I, anexo 3, folio 1962).

${ }^{43}$ Cfr. artículo 7 del Reglamento sobre el Secreto o Reserva de los Actos y Documentos de la Administración del Estado (expediente de anexos al escrito de solicitudes y argumentos, tomo I, anexo 3, folio 1961).

${ }^{44}$ Cfr. artículo 8 del Reglamento sobre el Secreto o Reserva de los Actos y Documentos de la Administración del Estado (expediente de anexos al escrito de solicitudes y argumentos, tomo I, anexo 3, folio 1961).

${ }^{45}$ Cfr. artículo 9 del Reglamento sobre el Secreto o Reserva de los Actos y Documentos de la Administración del Estado (expediente de anexos al escrito de solicitudes y argumentos, tomo I, anexo 3, folio 1962). 
g) los actos y documentos de carácter "reservado" o "secreto" mantendrán dicho carácter por el plazo de 20 años, a menos que el Jefe de Servicio respectivo lo excluya de estas categorías a través de resolución fundada ${ }^{46}$.

57.37 Después de la entrada en vigencia del Decreto Supremo No 26 que establece el Reglamento sobre el Secreto o Reserva de los Actos y Documentos de la Administración del Estado (supra párr. 57.36), se emitieron aproximadamente 90 resoluciones, otorgando el carácter de secreto o reservados a una serie de actos administrativos, documentos y antecedentes en manos de órganos del Estado ${ }^{47}$.

57.38 El 29 de mayo de 2003 se publicó la Ley $\mathrm{N}^{0} 19.880^{48}$ sobre procedimientos administrativos, en la cual se incorporó el principio de publicidad en sus artículos 16, 17 incisos a) y d) y 39. En el artículo 16 se estipula que "salvo las excepciones establecidas por la ley o el reglamento, son públicos los actos administrativos de los órganos de la Administración del Estado y los documentos que le sirvan de sustento o complemento directo o esencial".

57.39 El 4 de octubre de 2004 la Contraloría General de la República emitió el Dictamen $\mathrm{N}^{\circ} 49.883^{49}$, en respuesta a una petición presentada por varias personas y organizaciones, quienes impugnaron la legalidad de 49 resoluciones de declaración de secreto o reserva. Dicho dictamen señaló que "en numerosas resoluciones se excede la normativa a los efectos de la declaración de secreto o reserva en otros órdenes de materias", y que "en diversas resoluciones se fijan materias sujetas a secreto o reserva en términos de tal amplitud que no resulta admisible entenderlas amparadas por la regulación legal y reglamentaria que debe servirles de fundamento". En el referido dictamen la Contraloría señaló que "debe observarse que en distintas resoluciones no se advierte el fundamento preciso para declarar secretos o reservados determinados documentos". Con base en las anteriores consideraciones, la Contraloría ordenó de manera perentoria a todas las reparticiones que "las reexaminen a la brevedad [...] y, en los casos en que corresponda, las modifiquen en términos que se ajusten a la normativa que les sirve de fundamento".

${ }^{46}$ Cfr. artículo 10 e) del Reglamento sobre el Secreto o Reserva de los Actos y Documentos de la Administración del Estado (expediente de anexos al escrito de solicitudes y argumentos, tomo I, anexo 3 , folio 1963).

${ }^{47} \mathrm{Cfr}$. resoluciones administrativas de diversos órganos del Estado que califican como reservado o secreto información (expediente de anexos al escrito de solicitudes y argumentos, tomo I, anexo 4, folios 11641184); Open Society Institute and PARTICIPA, Chilean Report "Monitoring the Access to Public Information", Noviembre 2004 (expediente de anexos al escrito de solicitudes y argumentos, anexo 9, folios 1615 a 1634); y dictamen pericial rendido por el señor Carlos Carmona Santander ante la Corte Interamericana durante la audiencia pública celebrada el 3 de abril de 2006.

${ }^{48}$ Cfr. ley No. 19.980 publicada en el Diario Oficial el 29 de mayo de 2003 (prueba para mejor resolver incorporada por la Corte Interamericana, disponible en http://www.conicyt.cl/directorio/legislacion/ley19980.html).

${ }^{49}$ Cfr. dictamen $\mathrm{N}^{\circ} 49.883$ de 4 de octubre de 2004 (expediente de anexos al escrito de solicitudes y argumentos, tomo I, anexo 5, folios 1186 a 1196). 
57.40 El 4 de enero de 2005 dos senadores presentaron un proyecto de ley sobre acceso a la información pública ${ }^{50}$. En la exposición de motivos se señaló que "[a] pesar de los esfuerzos legislativos [realizados a través de la Ley de Probidad de 1999 y la Ley No. 19.880 de 29 de mayo de 2003], en la práctica [1]os principios de transparencia y de acceso a la información pública, se encuentran seriamente limitados, llegando a convertir estas leyes en letra muerta $[\ldots$, lo cual se debe al hecho que la misma ley de probidad dispone que uno o mas reglamentos establecerán los casos de secreto o reserva de la documentación y antecedentes que obren en poder de la administración del Estado, lo que constituye una seria barrera al derecho de acceso a la información pública establecido en la ley".

57.41 El 26 de agosto de 2005 entró en vigencia la Ley $\mathrm{N}^{\circ}$ 20.050, mediante la cual se realizó una reforma a la Constitución Política de la República. Entre otras reformas sustantivas, incorpora un nuevo artículo $8^{\circ}$ que establece que

[e]l ejercicio de las funciones públicas obliga a sus titulares a dar estricto cumplimiento al principio de probidad en todas sus actuaciones. Son públicos los actos y resoluciones de los órganos del Estado, así como sus fundamentos y los procedimientos que utilicen. Sin embargo, sólo una ley de quórum calificado podrá establecer la reserva o secreto de aquéllos o de éstos, cuando la publicidad afectare el debido cumplimiento de las funciones de dichos órganos, los derechos de las personas, la seguridad de la Nación o el interés nacional ${ }^{51}$.

La disposición transitoria quinta de la Constitución de Chile establece que "[s]e entenderá que las leyes actualmente en vigor sobre materias que conforme a esta Constitución deben ser objeto de leyes orgánicas constitucionales o aprobadas con quórum calificado, cumplen estos requisitos y seguirán aplicándose en lo que no sean contrarias a la Constitución, mientras no se dicten los correspondientes cuerpos legales" 52 .

57.42 El 7 de octubre de 2005 el Senado de la República de Chile aprobó al Proyecto de Ley sobre acceso a la información pública que modifica el Decreto con fuerza de ley $\mathrm{N}^{\circ} 1$ que fijó el texto refundido, coordinado y sistematizado de la Ley Orgánica sobre Bases Generales de la Administración del Estado, para "alcanzar un alto grado de transparencia en el ejercicio de las funciones públicas [y facilitar] la formación de una mayor y más efectiva participación ciudadana en los asuntos públicos" 53 . Actualmente dicho proyecto se encuentra en su segundo trámite constitucional.

${ }^{50}$ Cfr. proyecto de Ley $\mathrm{N}^{\circ}$ 3773-06 de Acceso a la Información Pública (expediente de anexos al escrito de contestación a la demanda y de observaciones al escrito de solicitudes y argumentos, anexo 7, folios 2261 a 2270); y Proyecto de Ley $\mathrm{N}^{\circ}$ 3773-06 de Acceso a la Información Pública (prueba para mejor resolver incorporada por la Corte Interamericana, disponible en http://sil.senado.cl/pags/index.html).

${ }^{51}$ Cfr. ley No. 20.050 publicada en el Diario Oficial el 26 de agosto de 2005 (expediente de anexos al escrito de solicitudes y argumentos, anexo I, folios 1088 a 1107).

${ }^{52}$ Cfr. quinta Disposición Transitoria de la Constitución Política de Chile, supra nota 36.

${ }^{53}$ Cfr. proyecto de Ley No 3773-06 de Acceso a la Información Pública (expediente de anexos al escrito de contestación a la demanda y de observaciones al escrito de solicitudes y argumentos, anexo 7, folios 2261 
57.43 El 12 de diciembre de 2005 el Ministerio Secretaría General de la Presidencia emitió el Decreto $N^{\circ} 134$, mediante el cual derogó el Decreto Supremo No. 26 de 2001 (supra párr. 57.36), con fundamento en que luego de la reforma que introdujo el nuevo artículo 8 de la Constitución (supra párr. 57.40) el contenido del referido Decreto "se ha transformado en contrario a la norma constitucional, no pudiendo, por tanto subsistir en el ordenamiento jurídico" 54 .

57.44 El 30 de enero de 2006 el Ministro Secretario General de la Presidencia remitió a diversas autoridades del Estado una comunicación, la cual consiste en una "guía que describe los criterios y reglas actualmente aplicables en materia de publicidad y acceso a la información administrativa”, dado que, como "consecuencia de la derogación [del Decreto No. 26,] han quedado también derogadas tácitamente todas las Resoluciones dictadas al amparo de dicho Reglamento que establecieron casos de secreto o reserva de actos y documentos de la Administración" 55 .

57.45 El 15 de febrero de 2006 la Comisión Asesora Presidencial para la Protección de los Derechos de las Personas ${ }^{56}$ informó a la Corte que "ha tomado iniciativa frente a algunos organismos de la Administración del Estado para exhortarlos, de manera oficiosa, a que den respuesta a las demandas de obtención de información planteadas por particulares y, especialmente, por personas jurídicas sin fines de lucro”. Sin embargo, dicha Comisión informó que en general los resultados han sido "infructuosos por cuanto la legislación vigente en la materia reserva a un procedimiento contencioso administrativo especial [...] la dilucidación del conflicto planteado entre el requirente de la información y el servicio público requerido. [...] Estando pues reservada a la competencia judicial la decisión sobre si procede o no entregar la información pública que el ciudadano demanda, la lógica inclinación de los jefes de servicios ante esta clase de requerimientos es esperar que el tribunal competente se los ordene", dado que sólo así se "relevará de responsabilidad ante eventuales reclamos de terceros" 57 .

\footnotetext{
a 2270); y Proyecto de Ley No 3773-06 de Acceso a la Información Pública (prueba para mejor resolver incorporada por la Corte Interamericana, disponible en http://sil.senado.cl/pags/index.html).

${ }^{54}$ Cfr. decreto $\mathrm{N}^{\circ} 134$ emitido el 12 de diciembre de 2005 por el Ministerio Secretaría General de la Presidencia (expediente sobre el fondo y eventuales reparaciones y costas, tomo II, folio 539).

${ }^{55} C f r$. oficio sin fecha firmado por el Ministro Secretario General de la Presidencia (expediente sobre el fondo y eventuales reparaciones y costas, tomo II, folio 541).

${ }^{56}$ Cfr. decreto Supremo $\mathrm{N}^{\circ} 65$ de 11 de mayo de 2001 (expediente de anexos al escrito de solicitudes y argumentos, anexo I, folios 1088 a 1107); e informe emitido el 15 de febrero de 2006 por el Presidente de la Comisión Asesora Presidencial para la Protección de los Derechos de las Personas (expediente sobre fondo y eventuales reparaciones y costas, tomo II, folios 554 y 556).

${ }^{57}$ Cfr. informe emitido el 15 de febrero de 2006 por el Presidente de la Comisión Asesora Presidencial para la Protección de los Derechos de las Personas (expediente sobre fondo y eventuales reparaciones y costas, tomo II, folios 554 y 556); y declaración escrita rendida por el perito Davor Harasic el 7 de marzo de 2006 (expediente sobre fondo y eventuales reparaciones y costas, tomo II, folios 509 a 518).
} 
Sobre las costas y gastos

[...]

VII. Violación del artículo i 3 De la Convención Americana

EN RELACIÓN CON LOS ARTÍCULOS I.I Y 2 DE LA MISMA

(LIBERTAD DE PENSAMIENTO Y DE EXPRESIÓN)

$[\ldots]$

\author{
VIII. Artículo 23 (Derechos Políticos) \\ De la Convención Americana \\ EN RELACIÓN CON LOS ARTÍCULOS I. I Y 2 DE LA MISMA
}

$[\ldots]$

IX. Violación DE LOS ARTí́CUlOS 8 Y 25

(Garantías Judiciales y Protección Judicial) de la Convención

EN RELACIÓN CON EL ARTÍCULO I. I DE LA MISMA

108. La Comisión no alegó ninguna violación del artículo 8 de la Convención, pero en cuanto al artículo 25, en relación con los artículos 1.1 y 2 de dicho tratado, indicó que:

a) la falta de un recurso judicial efectivo para reparar violaciones de derechos protegidos por la Convención constituye una violación de la misma. La efectividad del recurso implica que el órgano judicial evalúe los méritos de la denuncia; $y$

b) el Estado tiene la obligación de brindar un recurso judicial efectivo ante las presuntas violaciones al derecho de acceso a la información. Chile no otorgó ese recurso a las presuntas víctimas de este caso, toda vez que "la justicia chilena nunca intentó siquiera superficialmente determinar los derechos de las víctimas", "ni ha asegurado un mecanismo o un procedimiento adecuado para que una persona pueda acceder a una instancia judicial reguladora independiente y eficaz para garantizar el derecho del acceso a la información de los requirentes".

109. El representante de las presuntas víctimas presentó sus alegatos sobre las presuntas violaciones a los artículos 8 y 25, en relación con los artículos 1.1 y 2 de dicho tratado, de forma conjunta, por lo que así se resumen a continuación:

a) la Corte de Apelaciones de Santiago no conoció la petición de los recurrentes, sino que la declaró inadmisible "sin desarrollar en forma alguna el razonamiento para arribar a dicha conclusión”, y ese criterio fue ratificado por la 
Corte Suprema. Dicha "declaración de inadmisibilidad del recurso impidió que las víctimas fuer[a]n oídas con las debidas garantías para la satisfacción del derecho reclamado"; y

b) en sus alegatos finales señaló que el Estado incumplió lo dispuesto en los artículos 1 y 2 de la Convención, ya que el procedimiento formal de tramitación del recurso judicial para la protección de los derechos fundamentales, contenido en el artículo 20 de la Constitución chilena, no se encuentra incorporado al ordenamiento mediante ley como lo exige la Convención, sino mediante resolución de la Corte Suprema. La práctica del Poder Judicial muestra una aplicación restrictiva de los criterios de admisibilidad de dicho recurso. Solicitó a la Corte que declare que el auto acordado de la Corte Suprema de Justicia que regula el referido recurso "vulnera [los] artículo[s] 8 y 25 de la Convención”.

110. El Estado no se refirió a la supuesta violación del artículo 8 de la Convención Americana, pero en relación al artículo 25 indicó que:

a) el artículo 25 de la Convención "impone al Estado una obligación de medios y no de resultados”. A partir de 1999, Chile cuenta con un recurso de habeas data que ofrece "todas las garantías necesarias para obtener el acceso a la información pública”. Este recurso puede ser interpuesto en cualquier momento, por lo tanto las supuestas víctimas, en caso de negativa de información, pudieron haberlo interpuesto; y

b) las presuntas víctimas, "entre las que se encontraba el Diputado Arturo Longton”, disponían además de otro recurso en el orden interno ante la Cámara de Diputados, el cual pudieron interponer. Anunciaron su interposición, pero nunca lo hicieron a pesar de su efectividad. Mediante este recurso cualquier diputado "podrá solicitar, en el tiempo destinado a los incidentes, informes o antecedentes específicos a los organismos de la Administración del Estado a través de la Secretaría de la Cámara de Diputados”.

\section{Consideraciones de la Corte}

111. En cuanto a la alegada violación del artículo 8 de la Convención, esta Corte reitera su jurisprudencia sobre la posibilidad de que las presuntas víctimas o sus representantes invoquen derechos distintos de los comprendidos en la demanda de la Comisión ${ }^{58}$.

112. Como ha quedado establecido en los hechos probados (supra párr. 57.12 a 57.17 y 57.23 a 57.30), el Vicepresidente Ejecutivo del Comité de Inversiones Extranjeras (en el ámbito administrativo) y la Corte de Apelaciones de Santiago (en el ámbito judicial) adoptaron decisiones en relación con la solicitud de acceso a informa-

${ }^{58}$ Cfr. Caso Acevedo Jaramillo y otros. Sentencia de 7 de febrero de 2006. Serie C No. 144, párr. 280; Caso López Álvarez, supra nota 72, párr. 82; y Caso de la Masacre de Pueblo Bello. Sentencia de 31 de enero de 2006. Serie C No. 140, párr. 54. 
ción bajo el control del Estado realizada por los señores Claude Reyes y Longton Guerrero.

113. En primer término, la Corte analizará si la referida decisión administrativa fue adoptada de conformidad con la garantía de la debida fundamentación protegida en el artículo 8.1 de la Convención. En segundo lugar, el Tribunal determinará si la decisión judicial cumplió con dicha garantía y si, en el presente caso, Chile garantizó el derecho a un recurso sencillo y rápido o a cualquier otro recurso efectivo consagrado en el artículo 25.1 de la Convención.

\section{1) Aplicación del artículo 8.1 de la Convención respecto de la decisión del órgano} administrativo

114. El artículo 8.1 de la Convención señala que:

1. Toda persona tiene derecho a ser oída, con las debidas garantías y dentro de un plazo razonable, por un juez o tribunal competente, independiente e imparcial, establecido con anterioridad por la ley, en la sustanciación de cualquier acusación penal formulada contra ella, o para la determinación de sus derechos y obligaciones de orden civil, laboral, fiscal o de cualquier otro carácter.

115. Seguidamente, la Corte analizará si en el presente caso Chile cumplió con la garantía de la fundamentación de la decisión adoptada por el Vicepresidente del Comité de Inversiones Extranjeras, de acuerdo a la cual no se entregó una parte de la información solicitada.

116. El artículo 8 de la Convención Americana se aplica al conjunto de requisitos que deben observarse en las instancias procesales, cualesquiera que ellas sean, a efecto de que las personas puedan defenderse adecuadamente ante cualquier acto emanado del Estado que pueda afectar sus derechos 59 .

117. De acuerdo a lo dispuesto en el artículo 8.1 de la Convención, en la determinación de los derechos y obligaciones de las personas, de orden penal, civil, laboral, fiscal o de cualquier otro carácter, se deben observar "las debidas garantías" que aseguren, según el procedimiento de que se trate, el derecho al debido proceso $^{60}$. El incumplimiento de una de esas garantías conlleva una violación de dicha disposición convencional.

118. El artículo 8.1 de la Convención no se aplica solamente a jueces y tribunales judiciales. Las garantías que establece esta norma deben ser observadas en los distintos procedimientos en que los órganos estatales adoptan decisiones sobre la determinación de los derechos de las personas, ya que el Estado también otorga a autoridades administrativas, colegiadas o unipersonales, la función de adoptar decisiones que determinan derechos.

${ }^{59}$ Cfr. Caso YATAMA, supra nota 86, párr. 147; Caso Ivcher Bronstein, supra nota 72, párr. 102; Caso Baena Ricardo y otros. Sentencia de 2 de febrero de 2001. Serie C No. 72, párr. 124; y Caso del Tribunal Constitucional. Sentencia de 31 de enero de 2001. Serie C No. 71, párr. 69.

${ }^{60}$ Cfr. Caso YATAMA, supra nota 86, párrs. 148-164; y Caso Baena Ricardo y otros, supra nota 94, párrs. 127-134. 
119. De esta forma, las garantías contempladas en el artículo 8.1 de la Convención son también aplicables al supuesto en que alguna autoridad pública adopte decisiones que determinen tales derechos ${ }^{61}$, tomando en cuenta que no le son exigibles aquellas propias de un órgano jurisdiccional, pero sí debe cumplir con aquellas garantías destinadas a asegurar que la decisión no sea arbitraria.

120. La Corte ha establecido que las decisiones que adopten los órganos internos que puedan afectar derechos humanos deben estar debidamente fundamentadas, pues de lo contrario serían decisiones arbitrarias ${ }^{62}$.

121. Como ha quedado probado (supra párr. 57.17), frente a la solicitud de información bajo control del Estado planteada por los señores Claude Reyes y Longton Guerrero, el Vicepresidente Ejecutivo del Comité de Inversiones Extranjeras decidió negar una parte de la información. Como ha sido analizado por este Tribunal (supra párrs. 88 a 103), la referida decisión que adoptó dicho funcionario afectó negativamente el ejercicio del derecho a la libertad de pensamiento y de expresión de los señores Marcel Claude Reyes y Arturo Longton Guerrero.

122. En el presente caso la autoridad estatal administrativa encargada de resolver la solicitud de información no adoptó una decisión escrita debidamente fundamentada, que pudiera permitir conocer cuáles fueron los motivos y normas en que se basó para no entregar parte de la información en el caso concreto y determinar si tal restricción era compatible con los parámetros dispuestos en la Convención, con lo cual dicha decisión fue arbitraria y no cumplió con la garantía de encontrarse debidamente fundamentada protegida en el artículo 8.1 de la Convención.

123. Por lo anteriormente indicado, la Corte concluye que la referida decisión de la autoridad administrativa violó el derecho a las garantías judiciales consagrado en el artículo 8.1 de la Convención, en relación con el artículo 1.1 de dicho tratado, en perjuicio de los señores Marcel Claude Reyes y Arturo Longton Guerrero.

2) Aplicación del artículo 8.1 de la Convención respecto de la decisión de la Corte de Apelaciones de Santiago y Derecho a un recurso sencillo y rápido o a cualquier otro recurso efectivo consagrado en el artículo 25.1 de la Convención

124. El artículo 25.1 de la Convención señala que:

1. Toda persona tiene derecho a un recurso sencillo y rápido o a cualquier otro recurso efectivo ante los jueces o tribunales competentes, que la ampare contra actos que violen sus derechos fundamentales reconocidos por la Constitución, la ley o la [...] Convención, aun cuando tal violación sea cometida por personas que actúen en ejercicio de sus funciones oficiales.

${ }^{61}$ Cfr. Caso YATAMA, supra nota 86, párr. 149; Caso Ivcher Bronstein, supra nota 72, párr. 105; y Caso Baena Ricardo y otros, supra nota 94, párr. 124.

${ }^{62}$ Cfr. Caso Palamara Iribarne, supra nota 72, párr. 216; y Caso YATAMA, supra nota 86, párr. 152. Asimismo, cfr. García Ruiz v. Spain (GC), no. 30544/96, § 26, ECHR 1999-I; y Eur. Court H.R., Case of H. v. Belgium, Judgment of 30 November 1987, Series A no. 127-B, para. 53. 
125.El artículo 2 establece que

[s]i el ejercicio de los derechos y libertades mencionados en el artículo 1 no estuviere ya garantizado por disposiciones legislativas o de otro carácter, los Estados Partes se comprometen a adoptar, con arreglo a sus procedimientos constitucionales y a las disposiciones de esta Convención, las medidas legislativas o de otro carácter que fueren necesarias para hacer efectivos tales derechos y libertades.

126. La Corte ha establecido que todos los órganos que ejerzan funciones de naturaleza materialmente jurisdiccional tienen el deber de adoptar decisiones justas basadas en el respeto pleno a las garantías del debido proceso establecidas en el artículo 8.1 de la Convención Americana ${ }^{63}$.

127. El Tribunal ha señalado que el recurso efectivo del artículo 25 de la Convención debe tramitarse conforme a las normas del debido proceso establecidas en el artículo 8.1 de la misma, todo ello dentro de la obligación general, a cargo de los mismos Estados, de garantizar el libre y pleno ejercicio de los derechos reconocidos por la Convención a toda persona que se encuentre bajo su jurisdicción (artículo $1.1)^{64}$. Por ello, el recurso de protección de garantías planteado ante la Corte de Apelaciones de Santiago debió tramitarse respetando las garantías protegidas en el artículo 8.1 de la Convención.

128. El artículo 25.1 de la Convención ha establecido, en términos amplios, la obligación a cargo de los Estados de ofrecer, a todas las personas sometidas a su jurisdicción, un recurso judicial efectivo contra actos violatorios de sus derechos fundamentales. Dispone, además, que la garantía allí consagrada se aplica no sólo respecto de los derechos contenidos en la Convención, sino también de aquéllos que estén reconocidos por la Constitución o por la ley ${ }^{65}$.

129. La salvaguarda de la persona frente al ejercicio arbitrario del poder público es el objetivo primordial de la protección internacional de los derechos humanos ${ }^{66}$. $\mathrm{La}$ inexistencia de recursos internos efectivos coloca a las personas en estado de indefensión ${ }^{67}$.

${ }^{63}$ Cfr. Caso Palamara Iribarne, supra nota 72, párr. 164; Caso YATAMA, supra nota 86, párr. 149; y Caso Ivcher Bronstein, supra nota 72, párr. 104.

${ }^{64}$ Cfr. Caso Ximenes Lopes, supra nota 2, párr. 193; Caso Palamara Iribarne, supra nota 72, párr. 163; y Caso de la Comunidad Moiwana. Sentencia de 15 de junio de 2005. Serie C No. 124, párr. 142.

${ }^{65}$ Cfr. Caso YATAMA, supra nota 86, párr. 167; Caso Cantos. Sentencia de 28 de noviembre de 2002. Serie C No. 97, párr. 52; Caso de la Comunidad Mayagna (Sumo) Awas Tingni. Sentencia de 31 de agosto de 2001. Serie C No. 79, párr. 111; y Garantías Judiciales en Estados de Emergencia (arts. 27.2, 25 y 8 Convención Americana sobre Derechos Humanos). Opinión Consultiva OC-9/87 del 6 de octubre de 1987. Serie A No. 9, párr. 23.

${ }^{66}$ Cfr. Caso Acevedo Jaramillo y otros, supra nota 93, párr. 213; Caso García Asto y Ramírez Rojas. Sentencia de 25 de noviembre de 2005. Serie C No. 137, párr. 113; y Caso Palamara Iribarne, supra nota 72, párr. 183.

${ }^{67}$ Cfr. Caso García Asto y Ramírez Rojas, supra nota 101, párr. 113; Caso Palamara Iribarne, supra nota 72, párr. 183; Caso Acosta Calderón. Sentencia de 24 de junio de 2005. Serie C No. 129, párr.92; y Opinión Consultiva OC-9/87, supra nota 100, párr. 23. 
130. La inexistencia de un recurso efectivo contra las violaciones de los derechos reconocidos por la Convención constituye una transgresión de la misma por el Estado Parte ${ }^{68}$. Los Estados Partes en la Convención tienen la responsabilidad de consagrar normativamente y de asegurar la debida aplicación de dicho recurso efectivo.

131. Para que el Estado cumpla lo dispuesto en el artículo 25 de la Convención no basta con que los recursos existan formalmente, sino que los mismos deben tener efectividad $^{69}$, en los términos de aquél precepto. La existencia de esta garantía “constituye uno de los pilares básicos, no sólo de la Convención Americana, sino del propio Estado de Derecho en una sociedad democrática en el sentido de la Convención"70. Esta Corte ha reiterado que dicha obligación implica que el recurso sea idóneo para combatir la violación, y que sea efectiva su aplicación por la autoridad competente ${ }^{71}$.

132. En el presente caso los señores Marcel Claude Reyes, Arturo Longton Guerrero y Sebastián Cox Urrejola interpusieron un recurso de protección ante la Corte de Apelaciones de Santiago el 27 de julio de 1998 (supra párr. 57.23), con fundamento, inter alia, en que "la conducta omisiva del Comité de Inversiones Extranjeras" afectaba la garantía constitucional contemplada en el artículo 19 N 12 ("libertad de emitir opinión y de informar") de la Constitución Política, "en relación con el artículo $5^{\circ}$ inciso 2 de la misma[ ${ }^{72}$ ] y los artículos 13.1 de la Convención Americana sobre Derechos Humanos y 19.2 del Pacto Internacional de Derechos Civiles y Políticos, toda vez que por su intermedio se configura[ba] una omisión arbitraria en el acceso a información pública, no permitida por el ordenamiento jurídico que inhabilita a los recurrentes [...] a efecto[s d]el control social sobre los órganos de la Administración del Estado".

133. El referido recurso de protección se encuentra contemplado en el artículo 20 de la Constitución Política, el cual puede ser interpuesto por una persona "por sí o por cualquiera a su nombre" ante la Corte de Apelaciones respectiva, cuando por "causa de actos u omisiones arbitrarios o ilegales, sufra privación, perturbación o amenaza en el legítimo ejercicio de los derechos y garantías” establecidos en determinados numerales del artículo 19 de la Constitución (supra párr. 57.24).

${ }^{68}$ Cfr. Caso YATAMA, supra nota 86, párr. 168; Caso de la Comunidad Indígena Yakye Axa. Sentencia de 17 de junio de 2005. Serie C No. 125, párr. 61; y Caso "Cinco Pensionistas". Sentencia de 28 de febrero de 2003. Serie C No. 98, párr. 136.

${ }^{69}$ Cfr. Caso Ximenes Lopes, supra nota 2, párr. 192; Caso Baldeón García, supra nota 2, párr. 144; y Caso Acevedo Jaramillo y otros, supra nota 93, párr. 213.

${ }^{70}$ Cfr. Caso Caso Ximenes Lopes, supra nota 2, párr. 192; Caso Baldeón García, supra nota 2, párr. 144; y Caso López Álvarez, supra nota 72, párr. 138.

${ }^{71}$ Cfr. Caso López Álvarez, supra nota 72, párr. 139; Caso Palamara Iribarne, supra nota 72, párr. 184; y Caso Acosta Calderón, supra nota 102, párr. 93.

${ }^{72}$ El cual dispone que "el ejercicio de la soberanía reconoce como limitación el respeto a los derechos esenciales que emanan de la naturaleza humana. Es deber de los órganos del Estado respetar y promover tales derechos, garantizados por esta Constitución, así como por los tratados internacionales ratificados por Chile y que se encuentren vigentes". 
134. Al pronunciarse sobre dicho recurso, la Corte de Apelaciones de Santiago no resolvió la controversia suscitada por la actuación del Vicepresidente del Comité de Inversiones Extranjeras, pronunciándose sobre la existencia o no en el caso concreto del derecho de acceso a la información solicitada, ya que la decisión judicial fue declarar inadmisible el recurso de protección interpuesto (supra párr. 57.25).

135. En primer término, este Tribunal encuentra que esa decisión judicial careció de fundamentación adecuada. La Corte de Apelaciones de Santiago únicamente señaló que adoptaba tal decisión con base en que de "los hechos descritos [...] y de los antecedentes aparejados al recurso, se desprende que éste adolece de manifiesta falta de fundamento". Además, la Corte de Apelaciones señaló que tenía presente que "el recurso de protección tiene por objeto restablecer el imperio del derecho cuando éste ha sido quebrantado por actos u omisiones arbitrarias o ilegales que amenazan, perturban o privan del ejercicio legítimo de alguna de las garantías taxativamente numeradas en el artículo 20 de la Constitución Política de la República, dejando a salvo las demás acciones legales”, sin desarrollar ninguna consideración al respecto.

136. La referida resolución judicial no contiene otra fundamentación que la señalada anteriormente. La Corte de Apelaciones de Santiago no realizó ni la más mínima indicación respecto de las razones por las que se "desprend[ía]" de los "hechos" y "antecedentes" del recurso su "manifiesta falta de fundamento". Tampoco realizó una evaluación respecto de si la actuación de la autoridad administrativa, al no entregar una parte de la información solicitada, guardaba relación con alguna de las garantías que pueden ser objeto del recurso de protección, o si procedía algún otro recurso ante los tribunales ordinarios.

137. El Estado debe garantizar que, ante la denegatoria de información bajo el control estatal, exista un recurso judicial sencillo, rápido y efectivo que permita que se determine si se produjo una vulneración del derecho del solicitante de información y, en su caso, se ordene al órgano correspondiente la entrega de la información. En este ámbito, dicho recurso debe ser sencillo y rápido, tomando en cuenta que la celeridad en la entrega de la información es indispensable en esta materia. De acuerdo a lo dispuesto en los artículos 2 y 25.2.b) de la Convención si el Estado Parte en la Convención no tiene un recurso judicial para proteger efectivamente el derecho tiene que crearlo.

138. Respecto de la alegada violación del artículo 25 de la Convención, Chile se limitó a señalar que "los peticionarios ejercieron el recurso de protección de las garantías constitucionales sin obtener los resultados apropiados a sus pretensiones”, y explicó las reformas realizadas a partir de noviembre de 1999 que, inter alia, establecieron un "recurso [judicial] específico en materia de acceso a la información".

139. La Corte considera que en el presente caso Chile no cumplió con garantizar un recurso judicial efectivo que fuera resuelto de conformidad con el artículo 8.1 de la Convención y que permitiera que se resolviera el fondo de la controversia sobre la solicitud de información bajo el control del Estado, es decir, que se determinara si el Comité de Inversiones Extranjeras debía o no dar acceso a la información solicitada. 
140. La Corte valora los esfuerzos realizados por Chile en 1999 al crear un recurso judicial especial para amparar el acceso a la información pública. Sin embargo, es preciso indicar que las violaciones en el presente caso ocurrieron antes de que el Estado realizara tal avance en su legislación, por lo que no es de recibo el argumento del Estado de que las presuntas víctimas de este caso "pudieron haberlo interpuesto", ya que no se encontraba consagrado en la época de los hechos de este caso.

141. La Corte considera como víctimas a las tres personas que interpusieron el recurso judicial ante la Corte de Apelaciones de Santiago, quienes son los señores Marcel Claude Reyes, Arturo Longton Guerrero y Sebastián Cox Urrejola, ya que no obstante este Tribunal ha determinado que se violó el derecho a la libertad de pensamiento y de expresión solamente de Marcel Claude Reyes y Arturo Longton Guerrero (supra párrs. 69-71 y 103), correspondía al órgano judicial chileno pronunciarse en caso de que no hubiere lugar al recurso respecto de alguno de los recurrentes por motivos de legitimación activa.

142. Con base en lo expuesto, el Tribunal concluye que el Estado violó el derecho a la protección judicial consagrado en el artículo 25.1 de la Convención Americana, en relación con el artículo 1.1 de la misma, en perjuicio de Marcel Claude Reyes, Arturo Longton Guerrero y Sebastián Cox Urrejola, al no garantizarles un recurso sencillo, rápido y efectivo que les amparara ante actuaciones estatales que alegaban como violatorias de su derecho de acceso a la información bajo el control del Estado.

143. Asimismo, la Corte concluye que la referida decisión de la Corte de Apelaciones de Santiago que declaró inadmisible el recurso de protección no cumplió con la garantía de encontrarse debidamente fundamentada, por lo que el Estado violó el derecho a las garantías judiciales consagrado en el artículo 8.1 de la Convención, en relación con el artículo 1.1 de dicho tratado, en perjuicio de Marcel Claude Reyes, Arturo Longton Guerrero y Sebastián Cox Urrejola.

144. La pretendida violación a los artículos 8 y 25 de la Convención respecto de la regulación del procedimiento formal de tramitación del recurso judicial para la protección de los derechos fundamentales (supra párr. 109.b), no fue alegada por el representante en su debida oportunidad procesal. Sin embargo, la Corte estima necesario recordar que la regulación de la tramitación del recurso a que se refiere el artículo 25 de la Convención debe ser compatible con dicho tratado.

\section{Reparaciones}

Aplicación del artículo 63.1 de la Convención

Obligación de Reparar

[...]

Medidas de satisfacción y garantias de no repetición 


\section{C.1) Solicitud de información bajo el control del Estado}

157. En cuanto al argumento sostenido por Chile ante este Tribunal en el sentido de que ya no existe interés en la entrega de la información dado que el Proyecto "Río Cóndor" no se realizó, es preciso señalar que el control social que se buscaba con el acceso a la información bajo el control del Estado y el carácter de la información solicitada son motivos suficientes para atender al requerimiento de información, sin que deba exigirse al requirente que acredite una afectación directa o un interés específico.

158. Por lo tanto, debido a que en este caso el Estado no ha entregado una parte de la información solicitada y tampoco ha emitido una decisión fundamentada respecto de la petición de información, la Corte considera que el Estado, a través de la entidad correspondiente, debe entregar la información solicitada por las víctimas, en su caso, o adoptar una decisión fundamentada al respecto.

159. Si el Estado considera que no correspondía al Comité de Inversiones Extranjeras procurar una parte de la información que fue solicitada por las víctimas de este caso, deberá explicar fundamentadamente por qué no dio la información.

\section{C.2) Publicación de las partes pertinentes de la presente Sentencia}

160. Como lo ha dispuesto en otros casos, como medida de satisfacción ${ }^{73}$, el Estado deberá publicar en el Diario Oficial y en otro diario de amplia circulación nacional, por una sola vez, el capítulo relativo a los Hechos Probados de esta Sentencia, los párrafos 69 a 71, 73, 74, 77, 88 a 103, 117 a 123, 132 a 137 y 139 a 143 de la presente Sentencia, que corresponden a los capítulos VII y VIII sobre las violaciones declaradas por la Corte, sin las notas al pie de página correspondientes, y la parte resolutiva de la misma. Para esta publicación se fija el plazo de seis meses, a partir de la notificación de la presente Sentencia.

\section{C.3) Adopción de las medidas necesarias para garantizar el derecho de acceso a la información bajo el control del Estado}

161. La Corte también estima importante recordar al Estado que, de conformidad con lo dispuesto en el artículo 2 de la Convención, si el ejercicio de los derechos y libertades protegidos por dicho tratado no estuviere ya garantizado, tiene la obligación de adoptar las medidas legislativas o de otro carácter que fueren necesarias para hacer efectivos tales derechos y libertades.

162. La Corte valora los importantes avances normativos que Chile ha emprendido en materia de acceso a información bajo el control del Estado, que se encuentra en trámite un proyecto de Ley de Acceso a la Información Pública, así como los esfuerzos realizados al crear un recurso judicial especial para amparar el acceso a la información pública (supra párr. 57.35).

${ }^{73}$ Cfr. Caso Montero Aranguren y otros (Retén de Catia), supra nota 109, párr. 151; Caso Ximenes Lopes, supra nota 2, párr. 249; y Caso Baldeón García, supra nota 2, párr. 194. 
163. Sin embargo, el Tribunal considera necesario reiterar que el deber general comprendido en el artículo 2 de la Convención implica la supresión tanto de las normas como de las prácticas de cualquier naturaleza que entrañen violaciones a las garantías previstas en la Convención, así como la expedición de normas y el desarrollo de prácticas conducentes a la efectiva observancia de dichas garantías (supra párr. 64). Por ello, Chile debe adoptar las medidas necesarias para garantizar la protección al derecho de acceso a la información bajo el control del Estado, dentro de las cuales debe garantizar la efectividad de un procedimiento administrativo adecuado para la tramitación y resolución de las solicitudes de información, que fije plazos para resolver y entregar la información, y que se encuentre bajo la responsabilidad de funcionarios debidamente capacitados.

C.4) Realizar la capacitación a los órganos, autoridades y agentes públicos sobre el derecho de acceso a la información bajo el control del Estado

164. En el presente caso la autoridad administrativa encargada de resolver la solicitud de información de los señores Claude Reyes y Longton Guerrero observó una actitud vulneratoria del derecho de acceso a la información bajo el control del Estado. Al respecto, este Tribunal observa con preocupación que diversos elementos probatorios aportados al expediente de este caso coinciden en afirmar que los funcionarios públicos no responden efectivamente a solicitudes de información.

165. La Corte considera que el Estado debe realizar, en un plazo razonable, la capacitación a los órganos, autoridades y agentes públicos encargados de atender las solicitudes de acceso a información bajo control del Estado sobre la normativa que rige este derecho, que incorpore los parámetros convencionales que deben respetarse en materia de restricciones al acceso a dicha información (supra párrs. $77 \mathrm{y}$ 88 a 101).

D) $C \quad G$

$[\ldots]$

E) Modalidad de Cumplimiento

[...]

\section{Puntos Resolutivos}

174. Por tanto,

\section{LA CORTE}

\section{DECLARA,}

Por unanimidad, que:

1. El Estado violó el derecho a la libertad de pensamiento y de expresión consagrado en el artículo 13 de la Convención Americana sobre Derechos Humanos, en per- 
juicio de los señores Marcel Claude Reyes y Arturo Longton Guerrero, en relación con las obligaciones generales de respetar y garantizar los derechos y libertades y de adoptar disposiciones de derecho interno establecidas en los artículos 1.1 y 2 de dicho tratado, en los términos de los párrafos 61 a 103 de la presente Sentencia.

Por cuatro votos contra dos, que:

2. El Estado violó el derecho a las garantías judiciales consagrado en el artículo 8.1 de la Convención Americana sobre Derechos Humanos, en perjuicio de los señores Marcel Claude Reyes y Arturo Longton Guerrero, con respecto a la decisión de la autoridad administrativa de no entregar información, en relación con la obligación general de respetar y garantizar los derechos y libertades establecida en el artículo 1.1 de dicho tratado, en los términos de los párrafos 114 a 123 de la presente Sentencia.

Disienten el Juez Abreu Burelli y la Jueza Medina Quiroga.

Por unanimidad, que:

3. El Estado violó los derechos a las garantías judiciales y a la protección judicial consagrados en los artículos 8.1 y 25 de la Convención Americana sobre Derechos Humanos, en perjuicio de los señores Marcel Claude Reyes, Arturo Longton Guerrero y Sebastián Cox Urrejola, con respecto a la decisión judicial del recurso de protección, en relación con la obligación general de respetar y garantizar los derechos y libertades establecida en el artículo 1.1 de dicho tratado, en los términos de los párrafos 124 a 144 de la presente Sentencia.

Por unanimidad, que:

4. Esta Sentencia constituye per se una forma de reparación, en los términos del párrafo 156 de la misma.

\section{Y DECIDE,}

Por unanimidad, que:

5. El Estado debe, a través de la entidad correspondiente y en el plazo de seis meses, entregar la información solicitada por las víctimas, en su caso, o adoptar una decisión fundamentada al respecto, en los términos de los párrafos 157 a 159 y 168 de la presente Sentencia.

6. El Estado debe publicar, en el plazo de seis meses, en el Diario Oficial y en otro diario de amplia circulación nacional, por una sola vez, el capítulo relativo a los Hechos Probados de esta Sentencia, los párrafos 69 a 71, 73, 74, 77, 88 a 103, 117 a 123,132 a 137 y 139 a 143 de la presente Sentencia, que corresponden a los capítulos VII y VIII sobre las violaciones declaradas por la Corte, sin las notas al pie de página correspondientes, y la parte resolutiva de la misma, en los términos de los párrafos 160 y 168 de la presente Sentencia.

7. El Estado debe adoptar, en un plazo razonable, las medidas necesarias para garantizar el derecho de acceso a la información bajo el control del Estado, de acuerdo 
al deber general de adoptar disposiciones de derecho interno establecido en el artículo 2 de la Convención Americana sobre Derechos Humanos, en los términos de los párrafos 161 a 163 y 168 de la presente Sentencia.

8. El Estado debe realizar, en un plazo razonable, la capacitación a los órganos, autoridades y agentes públicos encargados de atender las solicitudes de acceso a información bajo el control del Estado sobre la normativa que rige este derecho, que incorpore los parámetros convencionales que deben respetarse en materia de restricciones al acceso a dicha información, en los términos de los párrafos 164 , 165 y 168 de la presente Sentencia.

9. El Estado debe pagar a los señores Marcel Claude Reyes, Arturo Longton Guerrero y Sebastián Cox Urrejola, en el plazo de un año, por concepto de costas y gastos, la cantidad fijada en el párrafo 167 de la presente Sentencia, en los términos de los párrafos 167 y 169 a 172.

10. Supervisará el cumplimiento íntegro de esta Sentencia, y dará por concluido el presente caso una vez que el Estado haya dado cabal cumplimiento a lo dispuesto en la misma. Dentro del plazo de un año, contado a partir de la notificación de esta Sentencia, el Estado deberá rendir a la Corte un informe sobre las medidas adoptadas para darle cumplimiento, en los términos del párrafo 173 de la presente Sentencia.

El Juez Abreu Burelli y la Jueza Medina Quiroga hicieron conocer a la Corte su Voto Disidente conjunto sobre el punto resolutivo segundo. El Juez García Ramírez hizo conocer a la Corte su Voto Concurrente Razonado sobre el punto resolutivo segundo. Dichos votos acompañan esta Sentencia.

Redactada en español e inglés, haciendo fe el texto en español, en San José, Costa Rica, el 19 de septiembre de 2006.

\title{
Sergio García Ramírez \\ Presidente
}

Alirio Abreu Burelli

Cecilia Medina Quiroga
Antônio A. Cançado Trindade

Manuel E. Ventura Robles

\author{
Diego García-Sayán \\ Pablo Saavedra Alessandri \\ Secretario
}

Comuníquese y ejecútese,

\author{
Sergio García Ramírez \\ Presidente
}

Pablo Saavedra Alessandri

Secretario 


\section{VOTO DISIDENTE DE LOS JUECES ALIRIO ABREU BURELLI Y CECILIA MEDINA QUIROGA}

1. Lamentamos disentir de la decisión de la Corte de aplicar el artículo 8.1 a la decisión del Vicepresidente del Comité de Inversiones Extranjeras de negar una información a las víctimas de este caso (ver párrafos 115 a 123 de la sentencia). El artículo 8.1 consagra el derecho a ser oído "con las debidas garantías y dentro de un plazo razonable, por un juez o un tribunal competente, independiente e imparcial...para la determinación de sus derechos y obligaciones de orden civil, laboral, fiscal, o de cualquier otro carácter". Esta disposición busca proteger el derecho de los individuos a que se resuelvan con la máxima justicia posible, las controversias que se susciten entre dos partes, sean ellas particulares u órganos del Estado y se refieran ellas a materias que estén o no en el ámbito de los derechos humanos. Esta disposición es, por excelencia, la garantía de todos los derechos humanos y un requisito sine qua non para la existencia de un Estado de derecho. Estimamos que su importancia no puede ser trivializada aplicándola a situaciones que, en nuestra opinión, no pueden ser objeto de esta regulación.

2. Es presupuesto para la aplicación de este derecho que se haya producido un desconocimiento por parte del Estado de algún derecho o que éste no haya amparado el desconocimiento del mismo por un particular. Producida la negación de un derecho la Convención crea a través del artículo 8 el derecho para las personas de que un órgano con las características que dicha disposición señala resuelva la controversia, es decir, el derecho a que se inicie un proceso, donde las partes que discrepan puedan, inter alia, argumentar en su favor, presentar pruebas, objetar al contrario.

3. Es claro que el caso que se examina en esta sentencia no constituye un proceso. Una petición de acceso a información y la negativa a otorgarlo no son un fenómeno jurídico en que un órgano del Estado, habilitado para ello, determina la aplicación del derecho en una situación concreta en la cual la norma que consagra el derecho ha sido controvertida o violada. Por el contrario, el acto de denegar el acceso a la información, crea la controversia y de allí emerge el derecho para los afectados de poder recurrir a un órgano que la decida, que resuelva el conflicto en razón de su jurisdicción y competencia. Este órgano en el ordenamiento jurídico del Estado es la Corte de Apelaciones respectiva a través del proceso que se inicia con la interposición de un recurso de protección. Transformar la secuencia "petición-negativa" en un proceso, exigiendo la aplicación del artículo 8 para tramitar la petición, implicaría sostener que esta petición debe ser recibida y decidida por un órgano independiente e imparcial y con todas las garantías que esta disposición establece (inter alia, el respeto a los principios de igualdad y de contradicción), puesto que el artículo 8.1 debe aplicarse en su integridad y cualquier elemento que se infrinja de él constituirá una violación del mismo. Esto traería consecuencias que no son quizás las más favorables para el peticionario en términos de dificultades y plazos. Significaría, a su vez, exigir para casos no penales la obligación de dos procedi- 
mientos jurisdiccionales, uno que regule la petición de la información y otro que revise su denegación, lo que no es una obligación de los Estados que emane de la Convención.

4. El hecho de que el artículo 8.1 se aplica a los procesos que determinan (y no que afectan) derechos u obligaciones y que se abre cuando un acto del Estado ha afectado un derecho, aparece claramente establecido por la Corte en los precedentes que cita en este fallo. En el caso del Tribunal Constitucional, en el que se examinaba la aplicación de una sanción de destitución de las tres víctimas por parte del Poder Legislativo (párr. 67), parte por sostener en su considerando 69 que, a pesar de que se titula "Garantías Judiciales", la aplicación del artículo 8.1 no se limita a los recursos judiciales en sentido estricto, sino que constituye "el conjunto de requisitos que deben observarse en las instancias procesales a efecto de que las personas puedan defenderse adecuadamente ante cualquier tipo de acto emanado del Estado que pueda afectar sus derechos". Agrega que el ejercicio del poder sancionatorio del Estado "no sólo presupone la actuación de las autoridades con un total apego al orden jurídico, sino implica además la concesión de las garantías mínimas del debido proceso a todas las personas que se encuentran sujetas a su jurisdicción, bajo las exigencias establecidas en la Convención (párr. 68). En el considerando 71 enfatiza que "si bien la función jurisdiccional compete eminentemente al Poder Judicial, otros órganos o autoridades públicas pueden ejercer funciones del mismo tipo", agregando que, en consecuencia, la expresión "juez o tribunal competente" exigible para la "determinación" de derechos, se refiere "a cualquier autoridad pública, sea administrativa, legislativa o judicial, que a través de sus resoluciones determine derechos y obligaciones de las personas". La Corte concluye este razonamiento sosteniendo que "cualquier órgano del Estado que ejerza funciones de carácter materialmente jurisdiccional, tiene la obligación de adoptar resoluciones apegadas a las garantías del debido proceso legal en los términos del artículo 8 de la Convención Americana”.

Esto significa que el artículo 8 se aplica cuando un órgano del Estado está ejerciendo facultades jurisdiccionales, lo que no parece posible argüir respecto de la negativa de un funcionario de proveer información a un particular. Acorde con su posición, la Corte, en el caso del Tribunal Constitucional, procede a examinar si la destitución de los jueces, presuntas víctimas en el caso, cumplió con todos y cada uno de los requisitos que este artículo exige, tales como la imparcialidad, independencia y competencia del órgano como el derecho de defensa del afectado (considerandos 74, 77, 81-84).

5. En el caso Baena, la Corte tiene esta misma posición, siendo la naturaleza del asunto semejante, pues se trataba también del ejercicio del poder sancionatorio del Estado (ver considerandos 124 y 131). En el caso Bronstein, el considerando 105 repite el párrafo 171 de la sentencia del Tribunal Constitucional y establece como fundamento de la violación del artículo 8 , los impedimentos que se le habían puesto a la víctima para defenderse, tales como no informarle de la pérdida de su expediente, no permitirle reconstruirlo, no comunicarle los cargos de que 
se le acusaba ni permitirle que presentara testigos (considerando 106). En el caso Yatama, la Corte repite su posición de que el artículo 8 se aplica a las "instancias procesales" (párrafo 147); sostiene que en el caso el Consejo Supremo Electoral ejercía funciones jurisdiccionales, no sólo por las actuaciones que realizó en ese caso sino porque la propia normativa nicaragüense describía esas funciones como jurisdiccionales (párrafo 151).

6. Nada de esto corresponde al caso que se examina. El acto que afectó el derecho del señor Claude Reyes y otros fue la negativa de un funcionario de permitir a un particular el acceso a una información; el proceso mediante el cual se reclamó de esta negativa fue el del recurso de protección y es por eso que hemos concurrido con la Corte a encontrar una violación del artículo 25, puesto que el tribunal de apelación chileno no cumplió con la norma mínima de toda resolución judicial, la de ser fundamentada.

7. Esta conclusión, sin embargo, no implica dejar el derecho de solicitar el acceso a una información al libre arbitrio del Estado. El derecho de petición a la autoridad, consagrado de manera general en los ordenamientos jurídicos de los países de la región y ciertamente en Chile (artículo 19, No. 14 de la Constitución Política de Chile) exige una respuesta del Estado, que debe ser, en las palabras de la Corte Constitucional de Colombia, "clara, pronta y sustancial" 74 . El derecho de petición no tendría sentido ni efecto útil si no exigiera esto del Estado. La falta de esta respuesta al señor Claude Reyes y otros ha constituido, en nuestra opinión, una violación al derecho constitucional de petición y, como esta petición era la de acceder a una información, reconocida en la Convención Americana como parte del derecho a la libertad de expresión, viola a ésta.

$\begin{array}{cc}\text { Alirio Abreu Burelli } & \text { Cecilia Medina Quiroga } \\ \text { Juez } & \text { Jueza }\end{array}$

Pablo Saavedra Alessandri

Secretario

\footnotetext{
${ }^{74}$ Sentencia T-281 de 1998. Magistrado Ponente Dr. Alejandro Martínez Caballero, Corte Constitucional Colombia.

Reproducida enwww.ramajudicial.gov.co, http://200.21.19.133/sentencias/programas/relatoria.
} 


\section{VOTO RAZONADO DEL JUEZ SERGIO GARCÍA RAMÍREZ PARA LA SENTENCIA DICTADA POR LA CORTE INTERAMERICANA DE DERECHOS HUMANOS EN EL CASO CLAUDE REYES Y OTROS VS. CHILE DEL I 9 DE SEPTIEMBRE DE 2006}

1. En un cuarto de siglo, la jurisprudencia de la Corte Interamericana ha debido explorar el sentido y alcance de numerosos derechos y libertades contenidos en la Convención Americana. Esta relectura del ordenamiento internacional, a la luz del objeto y fin del tratado -que se concentran en la tutela más amplia de los derechos humanos- y bajo el apremio de circunstancias renovadas, ha llevado a precisar evolutivamente el significado de los preceptos convencionales sin extraviar el rumbo de la Convención ni alterar su signo fundamental. Por el contrario, éstos se han afirmado y fortalecido. La relectura de los textos -característica de los tribunales constitucionales en el sistema nacional y de los tribunales convencionales en el internacional- permite mantener al día la tutela de los derechos y responder a las novedades que aporta el desarrollo en las relaciones entre el individuo y el poder público.

2. Así adquiere vigencia el concepto sustentado por la Corte Interamericana, informada en este extremo por la jurisprudencia europea, cuando afirma que "los tratados de derechos humanos son instrumentos vivos cuya interpretación tiene que acompañar la evolución de los tiempos y las condiciones de vida actuales. Tal interpretación evolutiva es consecuente con las reglas generales de interpretación consagradas en el (...) artículo 29 (de la Convención Americana), así como las establecidas en la Convención de Viena sobre el Derecho de los Tratados”.

3. Desde luego, nada de esto implica que el tribunal ponga en movimiento su imaginación y altere los lineamientos de la Convención, sin pasar por las instancias normativas formales. No se trata, en suma, de "reformar" el texto de aquélla, sino de desarrollar las decisiones jurídicas del ordenamiento para que mantenga su "capacidad de respuesta" frente a situaciones que los autores del instrumento no tuvieron a la vista, pero que implican cuestiones esencialmente iguales a las consideradas en esa normativa, y que traen consigo problemas específicos y requieren soluciones puntuales, extraídas, por supuesto, de los valores, principios y normas en vigor. En esta dirección ha marchado la jurisprudencia interamericana, gobernada por las disposiciones suscritas en 1969, en las que ha sabido encontrar, generalmente, el significado actual y pertinente para enfrentar y resolver las condiciones de cada nueva etapa. Abundan los ejemplos de este desarrollo.

4. Entre los temas examinados con mayor frecuencia por la Corte Interamericana se halla el llamado debido proceso legal, concepto desenvuelto por la regulación y la jurisprudencia angloamericana. El Pacto de San José no invoca, literalmente, el "debido proceso". Con otras palabras, sin embargo, organiza el sistema de audiencia, defensa y decisión entrañado en aquel concepto. Cumple esta misión -esencial para la tutela de los derechos humanos- con diversas expresiones y en distintos 
preceptos, entre ellos el artículo $8^{\circ}$, que figura bajo el rubro de "Garantías judiciales". Lo que se pretende con ello es asegurar al individuo que los órganos del Estado llamados a determinar sus derechos y deberes -en múltiples vertientes- lo harán a través de un procedimiento que provea a la persona con los medios necesarios para defender sus intereses legítimos y obtener pronunciamientos debidamente motivados y fundados, de manera que se halle bajo el amparo de la ley y al abrigo del arbitrio.

5. Si el destinatario de la tutela que ofrece la Convención y el aplicador de ésta se detienen en la letra de las expresiones, conforme fueron escritas hace varias décadas, limitará la expectativa de protección -aquél-y la posibilidad de otorgarla -éste- a los supuestos de juicio formal seguido ante los órganos judiciales. En efecto, el artículo $8^{\circ}$ alude a garantías "judiciales", y en seguida se refiere a un "juez o tribunal”. Sin embargo, este alcance limitado sería notoriamente insuficiente, hoy día, para alcanzar los objetivos que se ha propuesto el sistema internacional de protección de los derechos humanos. Si las garantías provistas por el artículo $8^{\circ}$, que gobierna los más relevantes asuntos de la tutela procesal, se contrajeran al desempeño de los órganos judiciales, quedaría en desamparo la definición de derechos y libertades que se realiza por otras vías, formalmente distintas de la judicial, pero materialmente cercanas a ésta en cuanto sirven al mismo fin: definir derechos y fijar deberes.

6. Por ejemplo, en diversos países la solución de las controversias entre la Administración Pública y el ciudadano se encomienda a los órganos judiciales; en otros, se entrega a órganos localizados fuera del Poder Judicial, bajo rubros jurisdiccionales o administrativos. En algunos Estados, la investigación de los delitos y la decisión sobre el empleo de la vía penal, una vez establecidos ciertos datos de hecho y derecho, queda en manos de una autoridad administrativa, el Ministerio Público -que ciertamente no es juez o tribunal-, mientras en otros se confía a jueces de instrucción, que tienen aquella naturaleza formal y material. Algunas decisiones trascendentales sobre afectación de propiedades, definición de derechos entre miembros de distintos sectores sociales, responsabilidad de servidores públicos y medidas de protección de niños y adolescentes (diferentes de las que son consecuencia de la violación de la ley penal) se han depositado en instancias judiciales, pero otras -que implican privación de derechos y sujeción a deberes- quedan a cargo de instancias de carácter diferente. Las experiencias nacionales históricas y contemporáneas permitirían agregar nuevos y abundantes ejemplos.

7. La jurisprudencia de la Corte Interamericana a propósito del debido proceso, la tutela judicial, las garantías procesales o la preparación y el ejercicio de la defensa de los particulares -expresiones que coinciden en una sola preocupación- ha desarrollado en sentido progresivo -invariablemente garantista- los datos del debido proceso. Esa jurisprudencia ha establecido, de esta forma, lo que denominé la "frontera actual del procedimiento" (Voto razonado a la Opinión Consultiva OC-16), que se mueve como resulta necesario, sin capricho ni aventura, para ajustar la defensa de los seres humanos frente a requerimientos emergentes. 
8. Así, la Corte ha establecido que el derecho del detenido extranjero a ser informado acerca de la asistencia consular que puede recibir - un derecho que no se plantea frente a órganos judiciales- constituye un derecho dentro del marco del debido proceso; que las garantías previstas en el proceso penal -contempladas en el párrafo 2 del artículo $8^{\circ}$ - son igualmente aplicables al procedimiento administrativo, en tanto éste implica, como aquél, una expresión del poder sancionador del Estado; que los derechos estatuidos en favor del inculpado en el ámbito penal deben ser atraídos, igualmente, a otros órdenes del procedimiento, en cuanto resulte aplicable a éstos, etcétera.

9. Todo ello $-\mathrm{y}$ desde luego me percato de que se trata de hipótesis de distinto signo, pero vinculadas por un mismo hilo conductor- pone de manifiesto una sola orientación tutelar que se identifica por el propósito de que las decisiones de las autoridades que definen derechos y deberes individuales, cualesquiera que aquéllas y éstos sean, satisfagan condiciones mínimas de objetividad, racionalidad y legalidad.

10. En el Caso Claude Reyes he sostenido que la decisión del órgano administrativo que dispuso la información a la que tendrían acceso los solicitantes y aquella otra que no podrían recibir, constituyó un acto de definición de derechos -en la especie, el derecho de buscar y recibir determinada información, en los términos del artículo 13 del Pacto de San José- en cuya emisión no se observaron ciertas garantías previstas en el artículo $8^{\circ}$ de la misma Convención. Esta inobservancia determinó que además de la afectación del artículo 13, sobre libertad de pensamiento y expresión, declarada por unanimidad de los integrantes de la Corte Interamericana, se presentase una vulneración del artículo $8^{\circ}$, a juicio de la mayoría, no seguido por dos integrantes de la Corte, por cuyo parecer tengo el mayor aprecio. De ahí que me permita expresar, en consecuencia de ese aprecio que me merecen mis colegas -lo mismo cuando coinciden que cuando difieren-, mis puntos de vista personales en un cotejo de opiniones legítimo y constructivo.

11. Obviamente, en la etapa administrativa de sus gestiones, los solicitantes de información no se encontraban dentro de un proceso judicial seguido ante un juez o tribunal, sino intervenían en un procedimiento administrativo desarrollado ante una autoridad de esta naturaleza. Sin embargo, ésta se hallaba obligada -en mi concepto- a actuar dentro del mismo cauce previsto por el artículo $8^{\circ}$, en todo lo que resultase pertinente y aplicable, en la medida en que su decisión definiría el derecho de los solicitantes.

12. La necesidad de atender las exigencias del artículo $8^{\circ}$ no deriva, a mi entender, del carácter de la autoridad dentro de la estructura del Estado, sino de la naturaleza de la función que ésta ejerce en el caso concreto y de la trascendencia que dicho ejercicio puede tener en relación con los derechos y los deberes del ciudadano que comparece ante ella, esgrimiendo el derecho que considera tener y aguardando la decisión fundada que debe recaer a la pretensión que manifiesta.

13. La decisión de aquella autoridad administrativa podía ser combatida ante un órgano judicial -como en efecto se intentó- para que éste dispusiera en defini- 
tiva, y la garantía del artículo 8.1 de la Convención era claramente aplicable al mencionado órgano judicial. Sin embargo, también es cierto que la existencia de un medio de control de la legalidad, por vía judicial, no implica que el primer tramo en el ejercicio del poder de decisión sobre derechos y deberes individuales quede sustraído a las garantías del procedimiento, a cambio de que éstas existan cuando se ingresa al segundo tramo de aquel ejercicio, una vez abierto un proceso ante la autoridad judicial. En rigor, es preciso observar las garantías en todas las etapas, cada una de las cuales lleva, de manera provisional o definitiva, a la determinación de los derechos. El control que la última etapa promete al particular, no justifica que en la primera -cualquiera que sea, técnicamente, su encadenamiento- se dejen de lado esas garantías con la expectativa de recibirlas posteriormente.

14. Considero, en fin, que las garantías del artículo $8^{\circ}$, en el sentido que encuentra en ellas la actual jurisprudencia de la Corte, no se aplican solamente al juicio o proceso, sino al procedimiento del que depende, como he señalado reiteradamente, la definición de derechos y deberes. De nuevo subrayo que esa aplicabilidad tiene el alcance que en cada caso permiten las características del procedimiento correspondiente. Por ello me refiero al deber de fundamentación y no a todos y cada uno de los deberes abarcados en el artículo $8^{\circ}$, tanto literalmente como a través de los renovados alcances que ha establecido la jurisprudencia interamericana.

\author{
Sergio García Ramírez \\ Juez \\ Pablo Saavedra Alessandri \\ Secretario
}

\title{
COMENTARio
}

El presente fallo es una excelente oportunidad para comentar el sentido de la expresión debido proceso y sus dos formas más corrientes en que se utiliza: como debido proceso procesal y debido proceso sustantivo.

Parece indicar la Corte Interamericana en su voto de mayoría que el debido proceso que garantiza el artículo $8^{\circ}$ de la Convención se aplica a todas las decisiones de los poderes del Estado que determinan los derechos de los ciudadanos. El fundamento 116 del fallo se refiere a "todas las instancias procesales". Se aplica por tanto a órganos jurisdiccionales como administrativos. Pero el voto de mayoría pone atención en que algunas de las garantías judiciales que reconoce la Convención sólo serán aplicadas respecto de órganos jurisdiccionales. No se podría exigir por tanto independencia e imparcialidad en la decisión de un órgano administrativo, pero sí que ésta esté debidamente justificada o fundamentada. En otras palabras, a los órganos jurisdiccionales se les exigirá un debido 
proceso procesal con todas las garantías que enuncia el artículo $8^{\circ}$ de la Convención y al órgano administrativo un debido proceso sustantivo al que se le deberán aplicar sólo algunas de las garantías del artículo $8^{\circ}$ de la Convención en cuanto garantizan la interdicción de la arbitrariedad en la decisión estatal. En este caso se exigió al órgano administrativo el deber de fundamentar la decisión.

Sin embargo, el voto de minoría de los jueces Alirio Abreu Burelli y Cecilia Medina Quiroga sostuvo una opinión contraria que me parece pertinente comentar. Parecen rechazar dichos jueces de minoría la idea de un debido proceso sustantivo aplicable a las autoridades administrativas. La clave para los jueces del voto de minoría está en la capacidad de determinar el derecho o en afectar el mismo creando así una controversia jurídica. Si el órgano es capaz de determinar el derecho, sea ese órgano judicial, administrativo o legislativo, según la tesis que parecen sostener los jueces de minoría en el fundamento número $4^{\circ}$ de su voto, se le aplican todas las garantías del artículo $8^{\circ}$ de la Convención. Si el órgano -normalmente administrativo- afecta y no determina un derecho, no le es exigible al mismo las garantías del artículo $8^{\circ}$ de la Convención.

El voto de minoría incurre en una contradicción que hay que destacar. En efecto, señalan dichos jueces de minoría que el artículo $8^{\circ}$ de la Convención debe aplicarse en su integridad a los entes públicos que tienen el poder de determinar los derechos de las personas y cualquier elemento que se infrinja de él constituirá una violación del mismo. Si ello es así, ¿cómo explican que a un órgano administrativo que por definición carece de independencia e imparcialidad se le puedan exigir dichas características? Si el legislador atribuye a un órgano administrativo el poder para determinar el derecho en un caso concreto, y si esa decisión no constituye una vía previa que podría ser impugnada en su integridad ante un verdadero tribunal de justicia, es decir iniciando un proceso de primera instancia, se estará siempre violando el artículo 8.1. de la Convención que garantiza el derecho a ser oído por un tribunal independiente e imparcial. No es consistente en esta parte el voto de minoría. Lo razonable es exigir todas las garantías del artículo $8^{\circ}$ sólo a los tribunales de justicia u órganos jurisdiccionales y sólo algunas de ellas a los demás poderes públicos que son capaces de determinar los derechos de las personas. En esta última situación están los órganos de la Administración del Estado.

Dicho lo anterior, hay que agregar que el fallo en cuestión, en el voto de mayoría, en ningún caso señala que el Comité de Inversiones Extranjeras chileno sea un tribunal de justicia o un órgano que ejerza jurisdicción. Al contrario, deja en claro que se trata de un órgano administrativo capaz de determinar la situación de los derechos de las personas. De hecho, esta parte de la fundamentación del fallo aparece bajo el título 1) "Aplicación del artículo 8.1. de la Convención respecto de la decisión del órgano administrativo [Comité de Inversiones Extranjeras]”. Precisamente por este poder que tiene reconocido legalmente el Comité de Inversiones Extranjeras, que es capaz de afectar derechos de las personas, se le exige que adopte su decisión en virtud de un debido proceso. Ese debido proceso, que hay que entenderlo en un sentido sustantivo, indica fundamentalmente interdicción de la arbitrariedad. 
Muy lejos del voto de mayoría y del de minoría está una de las doctrinas chilenas más seguidas en esta materia ${ }^{1}$. Me refiero a la tesis de Enrique Evans que considera como jurisdiccional cualquier decisión capaz de determinar o afectar los derechos de las personas. Esta tesis no es consistente con la Convención puesto que no puede ser considerada como jurisdiccional la actividad desarrollada por un órgano administrativo, toda vez que ella siempre vulnerará el artículo 8.1. Los órganos administrativos carecen por definición de independencia e imparcialidad, por lo que la actividad que se desarrolla ante ella y que es capaz de determinar o afectar los derechos de las personas nunca podrá respetar la garantía del artículo 8.1.

Tenemos de este modo que el debido proceso debe exigirse a todo órgano público capaz de determinar los derechos de las personas. Cuando ese órgano corresponda a un tribunal de justicia u órgano jurisdiccional deben aplicarse todas y cada una de las garantías del artículo $8^{\circ}$ de la Convención. Por el contrario, cuando la determinación de esos derechos la haga la Administración del Estado, como es el caso sub lite, sólo podrán exigirse algunas de las garantías del artículo $8^{\circ}$ de la Convención, como lo es el deber de fundamentar las decisiones. Lo importante es diferenciar que en el primer caso estamos frente a una actividad jurisdiccional y en el segundo ante actividad administrativa. Por eso podemos exigir independencia e imparcialidad respecto de los jueces y no de los administradores. Pero en ambos casos podemos exigir el deber de fundamentar sus decisiones.

La tesis de Evans que se comentaba más arriba supone un avance importante en un Estado de Derecho que proscribe la arbitrariedad del Estado. Pero implica asimismo un retroceso institucional de proporciones si se confunde la exigencia de debido proceso sustantivo que debe darse ante todo órgano público con la idea de que es jurisdiccional toda actuación de cualquier órgano público capaz de determinar o afectar los derechos de las personas. Desde luego esta tesis se carga el derecho fundamental a la tutela judicial, que nos garantiza que si, por ejemplo, la autoridad pública vulnera un determinado derecho, tenemos asegurada la vía ante un órgano jurisdiccional para deducir una pretensión de tutela. Y la garantía en este caso consiste en que la tutela la otorgará un órgano jurisdiccional, es decir, un órgano no político que goza de la garantía orgánica de la independencia en relación con los demás poderes políticos estatales, lo que le permite poder desarrollar imparcialmente las funciones asignadas constitucional y legalmente, aun contra los intereses de esos poderes políticos estatales.

\footnotetext{
${ }^{1}$ Enrique Evans de la Cuadra señala que "el administrador está ejerciendo una función jurisdiccional cuando, por ejemplo, impone sanciones, priva de la administración de bienes a sus dueños, temporal o definitivamente, desconoce el derecho de asociación negando arbitrariamente la personalidad jurídica, etc., y el reclamo ante la justicia ordinaria no es más que la continuación de ese proceso jurisdiccional ante un órgano de superior jerarquía”. Evans de la Cuadra, E. Los derechos fundamentales, Tomo II, Editorial Jurídica de Chile, $3^{a}$ edición, Santiago, 2004, p. 144. La posición de Evans está lejos del voto de mayoría del fallo de la Corte Interamericana porque describe derechamente como jurisdiccional la actividad de un órgano administrativo que determina o afecta derechos. Asimismo, está lejos del voto de minoría porque designa como jurisdiccional no sólo a la función de determinación de derechos sino a las decisiones administrativas que afectan derechos creando controversias jurídicas, como puede ser, por ejemplo, el caso que el autor expone de desconocer arbitrariamente la personalidad jurídica.
} 
En definitiva, según el criterio de la Corte, ante el Comité de Inversiones Extranjeras, aun en el caso de que decida sobre los derechos de una determinada persona, estamos frente a una actividad administrativa y no jurisdiccional. Por eso podemos exigirle un debido proceso sustantivo y no procesal. Confundir estos planos no es como supone un sector de la doctrina constitucional chilena ser más garantista, sino que implica una ostensible conculcación de los derechos de las personas. 